OPEN ACCESS

Edited by:

Pellegrino Musto,

National Research Council (CNR), Italy

Reviewed by:

Yanhu Zhan,

Liaocheng University, China

Ehsan Nazarzadeh Zare,

Damghan University, Iran

Giuseppe Scherillo,

University of Naples Federico II, Italy

${ }^{*}$ Correspondence:

Jegatha Nambi Krishnan

jegathak@goa.bits-pilani.ac.in

${ }^{\dagger}$ These authors have contributed equally to this work

Specialty section:

This article was submitted to

Polymer Chemistry

a section of the journal

Frontiers in Chemistry

Received: 22 September 2021 Accepted: 03 January 2022 Published: 28 January 2022

Citation:

Nambi Krishnan J, Venkatachalam KR, Ghosh O, Jhaveri K, Palakodeti A and

Nair N (2022) Review of Thin Film Nanocomposite Membranes and Their

Applications in Desalination.

Front. Chem. 10:781372.

doi: 10.3389/fchem.2022.781372

\section{Review of Thin Film Nanocomposite Membranes and Their Applications in Desalination}

\author{
Jegatha Nambi Krishnan ${ }^{1 *}$, Kaarthick Raaja Venkatachalam ${ }^{1}$, Oindrila Ghosh ${ }^{1}$, \\ Krutarth Jhaveri ${ }^{2+}$, Advait Palakodeti ${ }^{3+}$ and Nikhil Nair ${ }^{1}$ \\ ${ }^{1}$ Department of Chemical Engineering, Birla Institute of Technology and Science Pilani, K. K. Birla Goa Campus, Zuarinagar, India, \\ ${ }^{2}$ Strategic Engagement and Analysis Group, Rocky Mountain Institute, Boulder, CO, United States, ${ }^{3}$ Process and Environmental \\ Technology Lab, Department of Chemical Engineering, KU Leuven, Leuven, Belgium
}

All over the world, almost one billion people live in regions where water is scarce. It is also estimated that by 2035, almost 3.5 billion people will be experiencing water scarcity. Hence, there is a need for water based technologies. In separation processes, membrane based technologies have been a popular choice due to its advantages over other techniques. In recent decades, sustained research in the field of membrane technology has seen a remarkable surge in the development of membrane technology, particularly because of reduction of energy footprints and cost. One such development is the inclusion of nanoparticles in thin film composite membranes, commonly referred to as Thin Film Nanocomposite Membranes (TFN). This review covers the development, characteristics, advantages, and applications of TFN technology since its introduction in 2007 by Hoek. After a brief overview on the existing membrane technology, this review discusses TFN membranes. This discussion includes TFN membrane synthesis, characterization, and enhanced properties due to the incorporation of nanoparticles. An attempt is made to summarize the various nanoparticles used for preparing TFNs and the effects they have on membrane performance towards desalination. The improvement in membrane performance is generally observed in properties such as permeability, selectivity, chlorine stability, and antifouling. Subsequently, the application of TFNs in Reverse Osmosis (RO) alongside other desalination alternatives like Multiple Effect Flash evaporator and Multi-Stage Flash distillation is covered.

Keywords: reverse osmosis, thin film nanocomposite membrane, desalination, interfacial polymerization, chlorine resistance, antifouling, permeability

\section{INTRODUCTION}

The United Nations World Water Development Report 2020: Water and Climate Change states that in accordance with a study conducted by the 2030 Water Resources Group (WRG), the world will have only $60 \%$ of the water it needs by 2030 , if it continues on its current trajectory (UNESCO, 2020). This scarcity has risen out of the ever growing gap between the overwhelming demand, through agriculture, industries, urbanization, rapidly rising population; and the worryingly low supply of consumable water. This is where the importance of recycling water and converting the abundantly available seawater to usable form by the process of desalination becomes critical. Over the previous decade, membrane based technologies have developed significantly (The World Bank, 2007; Lind et al., 2009a; Li et al., 2013) and the growth in total desalination capacity across the world has been staggering. Among the different 


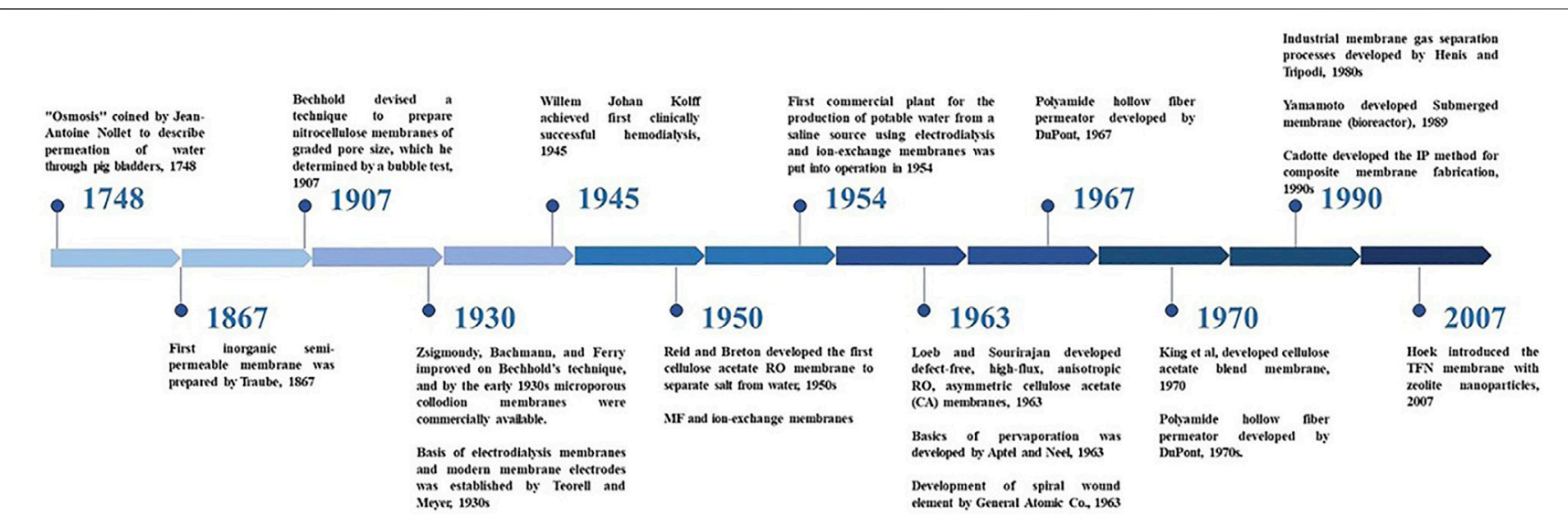

FIGURE 1 | History of the development of membrane technology.

desalination techniques such as electrodialysis, Mechanical Vapor Compression (MVC) and Nano-Filtration (NF), Reverse Osmosis (RO) is the most popularly used technique. Energy consumption of RO membranes in 2013 was $1.8 \mathrm{k} \mathrm{Wh}$, which makes the process much less energy intensive than the other available options, such as MSF (multi-stage flash distillation) and MEF (multiple effect flash distillation) (Buonomenna, 2013). Over 60\% of today's desalinated water comes through RO technology.

For the purpose of desalination and other similar applications, various kinds of membranes are fabricated like thin film composite membranes (TFCs) and thin film nanocomposite membranes (TFNs). TFNs are a modification of the existing TFCs prepared through interfacial polymerization (IP). The modification is in the form of nanoparticles being incorporated into a thin polyamide (PA) dense layer at the top of the TFC membrane, aimed at improving its performance (Jeong et al., 2007). This enhancement could be varied such as in the form of improved water permeability and solute rejection.

The TFN membrane was introduced by Hoek (Jeong et al., 2007 ) in which TFNs were synthesized by embedding zeolite $\mathrm{NaA}$ nanoparticles $(0.004-0.4 \% \mathrm{w} / \mathrm{v})$ in the PA layer. The PA layer of the composite membrane was made of $\mathrm{m}$-phenyldiamine (MPD) and trimesoyl chloride (TMC). This new concept showed a significant enhancement in the membrane flux while maintaining a comparable solute rejection to the traditionally prepared TFC membrane. This improvement in permeability due to the super-hydrophilic molecular sieve nanoparticle pores which provide distinct channels for the flow is ascribed (Jeong et al., 2007).The following section discusses the evolution of membrane technology from its first instance of application in a water separation process in 1748 to the currently produced more advanced TFNs.

\section{BACKGROUND AND HISTORY}

The application of membranes for separation of small solute particles from water was first reported in 1748 by Jean-Antoine Nollet (Williams, 2003). However, it was only in the 1850s that
Traube and Pfeffer became the first to study osmosis using ceramic membranes. In 1959, the first cellulose acetate RO membrane capable of separating salt from water was developed by C. E. Reid and E. J. Breton (Williams, 2003). These membranes had a very low flux due to the excess thickness a free standing membrane was required. It was in 1962 that a major advancement was made by Loeb and Sourirajan, who developed an anisotropic cellulose acetate membrane. It had a thin layer on top of a highly porous and thick substrate (Williams, 2003). This made RO a practical desalting process exhibiting salt rejection values of about 99.5\%. Subsequently, different types of designs such as tubular, hollow fiber, and spiral wound were developed as shown in Figure 1 to utilize the membranes on a commercial scale ( $\mathrm{Li}$ and Wang, 2013).

The Loeb-Sourirajan membrane became an industry standard until the 1970s, when the IP method for composite membrane fabrication was developed by John Cadotte of Dow FilmTec (Li and Wang, 2013). This involved placing an ultra-thin aromatic top layer on a porous ultrafiltration membrane via the IP process. The aromatic structure made it highly durable making it the technologically most advanced membrane at that time. The applications of these membranes have been extended to the removal of other dissolved solutes from various feed waters (Ex. FT-30 membrane developed by Cadotte at Dow FilmTec). Modifications in membrane design, configuration, and introduction of pre-treatment and post-processes allowed the energy consumption of RO desalination to be reduced from six $\mathrm{kWh} / \mathrm{m}^{3}$ (in the $1980 \mathrm{~s}$ ) to $1.8 \mathrm{kWh} / \mathrm{m}^{3}$ (Li and Wang, 2013). The FilmTec membranes continued to dominate the US market till Hoek introduced the first TFN membrane for brackish water reverse osmosis (BWRO) membranes in 2007. In that work, the membrane had zeolite nanoparticles dispersed in the organic solution of an interfacial polymerization reaction. This was commercialized in 2011 through a start-up called $\mathrm{NanoH}_{2} \mathrm{O}$ (NanoH2O and Inc. InterNano, 2021). Since then, TFNs have been at the center of attention in membrane technology. The following section delves deeper into the structure and synthesis of TFCs along with its limitations that make TFNs a better choice in most applications. 


\section{THIN FILM COMPOSITE MEMBRANES}

TFC membranes are the precursors to TFNs. Composite membranes are a type of asymmetrical membranes that have a dense top layer and a porous support made of different materials. Commercial RO membranes were initially obtained from two kinds of membranes: Polyamide (PA) and Cellulose Acetate (CA) (Li and Wang, 2010; Rana T. M. D. et al., 2011). PA TFCs have two layers; a porous substrate layer (usually made of polysulfone) and a thin layer made of polyamide formed on it ( $\mathrm{Li}$ and Wang, 2010). The top layer is concerned with permeation properties of the membrane, while the sub-layer, which is porous, provides mechanical strength and support. The advantage of having the two layers made of different chemicals is that each layer can be individually synthesized or customized so as to optimize the overall performance of the membrane (Louie et al., 2006).Compared to CA membranes, TFCs exhibit better salt rejection, water flux and resistance to biological attacks, apart from being able to operate at wider range of $\mathrm{pH}$ (varying from $1-11$ ) and temperatures (varying from $0-45^{\circ} \mathrm{C}$ ) (Li and Wang, 2010). The following subsection discusses the techniques involved in the fabrication of TFCs.

\subsection{Synthesis of TFCs}

The methods of fabrication include techniques such as IP, solution mixing and polymer melt blending (Kim and Deng, 2011) of which IP has been the most common since its introduction in 2007 (Jeong et al., 2007). Generally an asymmetric membrane prepared through phase inversion is the support layer (Ghosh and Hoek, 2009). Polymers generally used to form the support layers are polysulfone (PSF), polyimide (PI), polyethersulfone (PES), polyacrylonitrile (PAN), and polypropylene (PP) (Ghosh and Hoek, 2009). Various techniques can be used to deposit a thin layer on a porous sub-layer one of these is IP. The traditional synthesis technique requires the dissolution of a difunctional amine in water and a trifunctional acid halide in an organic solvent. The solvent is usually chosen such that water and the solvent are immiscible. The support membrane (usually PSF) is initially immersed in the aqueous solution and, after saturation, is then immersed into the organic phase. Upon immersing in the organic phase, there is a polymerization reaction between the monomers to form the thin layer (Ghosh and Hoek, 2009). Alternatively, there is another method of IP known as the SIM method. In this method, the organic phase is poured over the membrane as it already has amines present on it due to phase inversion. This method is more efficient as there is more complete wetting, which results in a more homogenous, defect-free layer as compared to the traditional methods (Hermans et al., 2014).

TFCs have been a boon to membrane based technologies. However, they do have some limitations. These have been discussed in sub Section 3.2.

\subsection{Limitations of TFCs}

One of the biggest advantages of a TFC is that one can control and optimize each layer individually to improve its function. A high solvent flux can be obtained without compromising on the salt rejection. In addition, they are also much stronger and more stable (Petersen, 1993). However, in spite of the above advantages, TFCs have a few limitations which cannot be neglected.

One of the main drawbacks is its low resistance to chlorine (Lau et al., 2012). Chlorination of the main group present in the PA layer increases the hydrophobic nature of the membrane, which in turn decreases flux (Hermans et al., 2015). Chlorine is abundantly present in waters to be treated as chlorination is an important disinfection and pre-treatment step. Therefore, this is a significant performance inhibitor. TFCs are also very susceptible to fouling over time by microorganisms or organic compounds which leads to decline or deterioration of membrane performance. The process of de-fouling increases costs and energy consumption. In addition, high temperatures can also cause collapsing or compactness of pores in the membrane (Hermans et al., 2015).

To overcome these limitations, various methods were developed with the intent to improve the fouling resistance and chlorine resistance of TFCs thereby increasing their performance. This can primarily be done through modifications in the substrate. The following subsection discusses this aspect in details.

\subsection{Methods of Membrane Modification 3.3.1 Modifications in the Substrate}

Polysulfones are very commonly used as a substrate for the fabrication of TFCs. In recent years, substantial research work has been conducted with the aim to enhancemembrane performance by modifying the substrate layer, either by the inclusion of organic solvents such as n-methyl pyrolidone in precipitation, or by addition of hydrophilic agents such as polyethylene glycol (Zhou et al., 2009). Methods that have been reported to increase the fouling resistance and chlorine stability have been discussed in the subsequent sub sections.

\subsubsection{Increase in the Fouling Resistance}

The fouling of the membrane can lead to decreased water flux, which in turn leads to increased energy consumption to pump water through membranes. TFCs can be modified by physical or chemical methods so as to reduce fouling (Li and Wang, 2010). Physical methods include applying a coating on the surface of the membrane without interfering with the chemical structure of the material. Polyvinyl alcohol and polyethyleneimine are some of the polymers that have been used in this manner in recent studies (Kim et al., 2004; Louie et al., 2006; Zhou et al., 2009). As an example, polyethyleneimine can invert surface charges on polyamide membranes so as to reduce fouling by cationic substances by electrostatic repulsion (Zhou et al., 2009).

Chemical modification methods can also be used to increase fouling resistance. Monomers can be covalently attached to the monomers on membrane surfaces by radiation or redox grafting methods. This modification of the surface of membranes can lead to a decrease in contaminant adsorption for certain polymers ( $\mathrm{Li}$ and Wang, 2010).

\subsubsection{Increase in Chlorine Stability}

The chlorine resistance of the PA layer of the membranes depends upon the chemical nature of the diamine structure. 


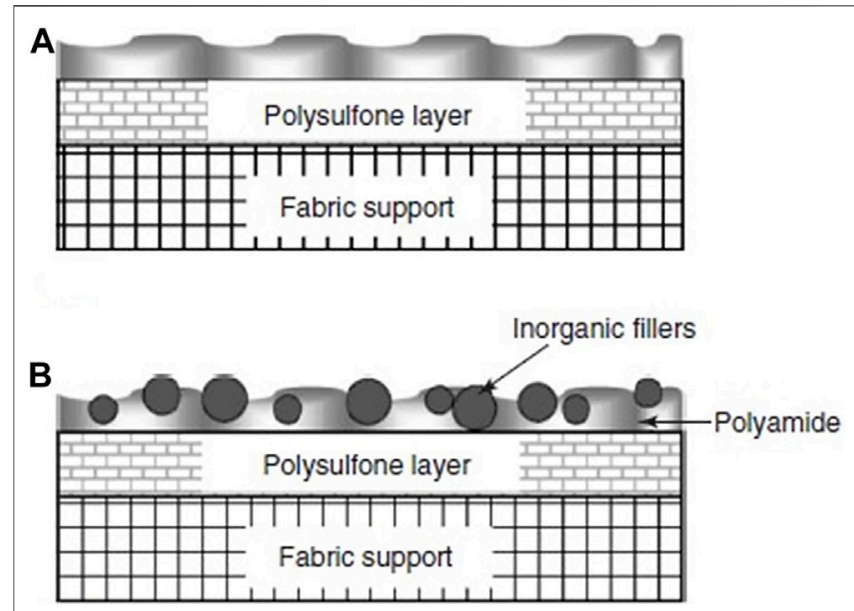

FIGURE 2 | Conceptual illustration of PA (A) TFC and (B) TFN membrane structures (Zhou et al., 2009).

Chlorine resistance will be high if the amino groups have the following structures: i)aromatic diamines that have a mono methyl or chlorine substitutes at the ortho position of the amino groups; or with amino groups at ortho-position, compared with those at meta- and para-position; ii) aliphatic or cycloaliphatic diamines that possess a secondary amino group or a short methylene chain length between end amino groups; iii) secondary aromatic diamines (Li and Wang, 2010).

Chlorine resistance can also be increased by the addition of certain types of monomers. For example, membranes produced via IP by introducing-OH functional group containing monomers such as m-aminophenol and bisphenol-A show greater chlorine resistance than MPD -TMC polyamide membranes (Li and Wang, 2010). Another method is incorporating ester linkages by substituting aromatic amines, as this reduces the number of available sites for chlorine attack (Li and Wang, 2010).

Incorporation of nanoparticles in TFCs results in TFNs. These have a large number of preferable characteristics. The details of TFNs have been discussed in Section 4 starting with the processes developed for the synthesis of the same.

\section{SYNTHESIS OF TFNS}

TFNs can be synthesized by IP, solution mixing or polymer melt blending (Kim and Deng, 2011). One of the more commonly used techniques is IP (Jeong et al., 2007). Preparation of TFNs takes place in almost the same manner as TFCs, except for a step which involves the addition of fillers. Figure 2 illustrates PA in both TFC and TFN membrane structures ( $\mathrm{Li}$ and Wang, 2010).

The fillers can be added to aqueous or organic phase (Figure 3) based on the properties of the nanoparticle fillers used. The membranes can be dipped into a nanoparticle solution (Shenvi et al., 2015). Once the nanoparticles are embedded in one of the phases, IP is carried out as per standard procedure (Figure 4). In IP, an aqueous amine solution is first used to impregnate a microporous film. This is followed by a treatment using a multivalent cross linking agent that has been dissolved in a organic fluid, that is immiscible with water, for example, hexane. As a result, a thin polymer film is obtained at the interface of the two solutions. Table 1 summarizes the methods of synthesis and the important properties of various TFNs reported in literature (Petersen, 1993; Kim et al., 2004; Louie et al., 2006; Ghosh and Hoek, 2009; Jadav and Singh, 2009; Zhou et al., 2009; Park K. T. et al., 2010; Li and Wang, 2010; Fathizadeh et al., 2011; Kim and Deng, 2011; Rana T. M. D. et al., 2011; Zhang et al., 2011; Lau et al., 2012; Huang et al., 2013a; Kim E. S. et al., 2013; Alam et al., 2013; Baroña et al., 2013; Chan et al., 2013; Pendergast et al., 2013; Shen et al., 2013; Hermans et al., 2014; Zhao et al., 2014; Ghanbari et al., 2015; Hermans et al., 2015; Safarpour et al., 2015; Shenvi et al., 2015).

\subsection{Position of Fillers}

It is difficult to regulate the position of the filler in TFNs. It has been reported that when $\mathrm{NaA}$ nanoparticles are dissolved in the aqueous phase, they are more concentrated near the porous sublayer as compared to near the surface of thin film. On the other hand, when $\mathrm{NaA}$ nanoparticles were dissolved in the organic phase, they were found to be homogeneously distributed with equal concentrations near the surface and the sublayer (Huang et al., 2013b). It has been reported that the position of the fillers in the membrane can be tuned by selecting an appropriate type of nanoparticle.

Additive nanomaterials have been demonstrated to improve the performance of TFNs. This has been discussed in the following section.

\section{NEW FUNCTIONALITIES INTRODUCED BY ADDITIVE NANOMATERIALS}

The addition of nanoparticles (NPs) provides significant improvements to the membrane performance(Liao et al., 2021).Moreover, the year wise publication status for TFN membranes is also shown in Figure 5. The various NPs that are added in order to aid the adsorption, photocatalysis and antimicrobial properties of TFNs have been discussed in the following subsections.

\subsection{Adsorption}

Membranes can be enabled to adsorb heavy metals from water by the incorporation of NPs inside the polymer matrix. Daraei developed a method to remove copper from aqueous solutions by incorporating $\mathrm{PANI} / \mathrm{Fe}_{3} \mathrm{O}_{4} \mathrm{NPs}$ inside the PES matrix through PI method (Daraei et al., 2012). Elsewhere, Fe-Mn binary oxide (FMBO) is used to remove As (III)] (Jamshidi Gohari et al., 2013). These highlight the possibility of nanocomposite membranes being incorporated with adsorbents for removal of contaminants.

\subsection{Photocatalysis}

$\mathrm{TiO}_{2}$ has been known for its photocatalytic properties and as a result has been used for applications such as water splitting, 


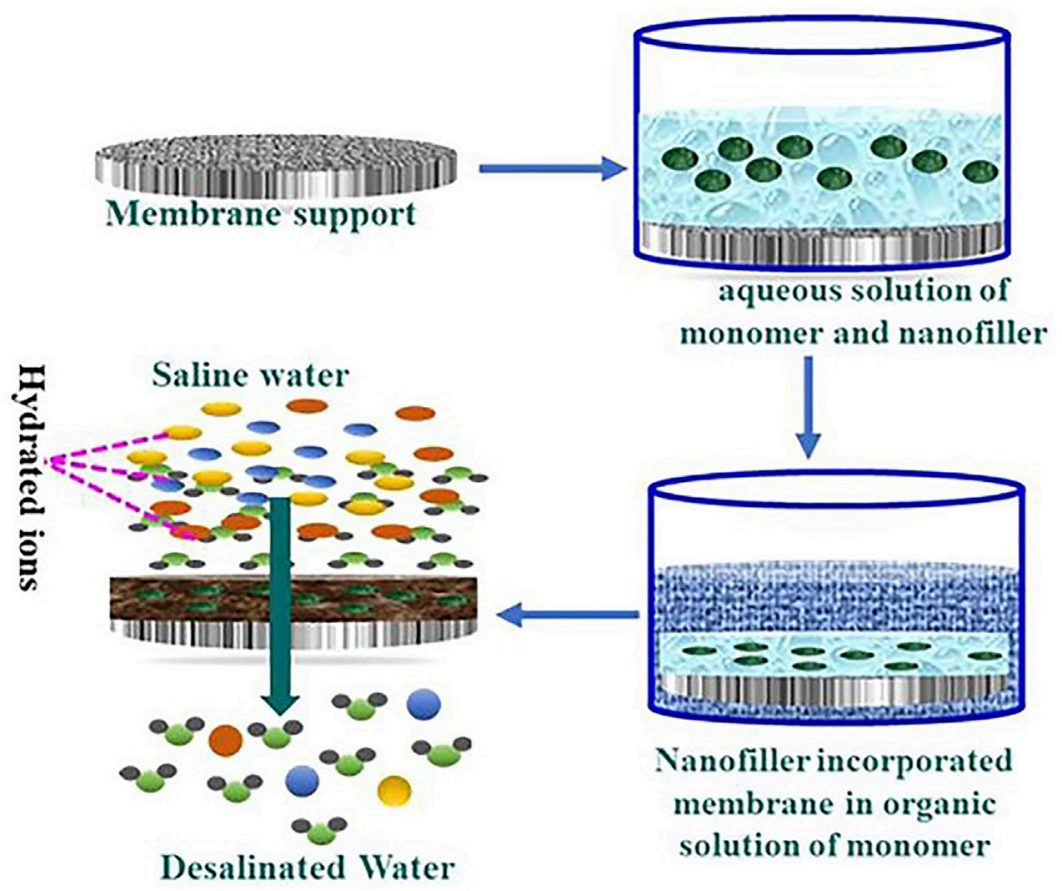

FIGURE 3 | Diagrammatic representation of manufacturing TFN membrane through interfacial polymerization in the presence of nanofillers (Kumar et al., 2020).

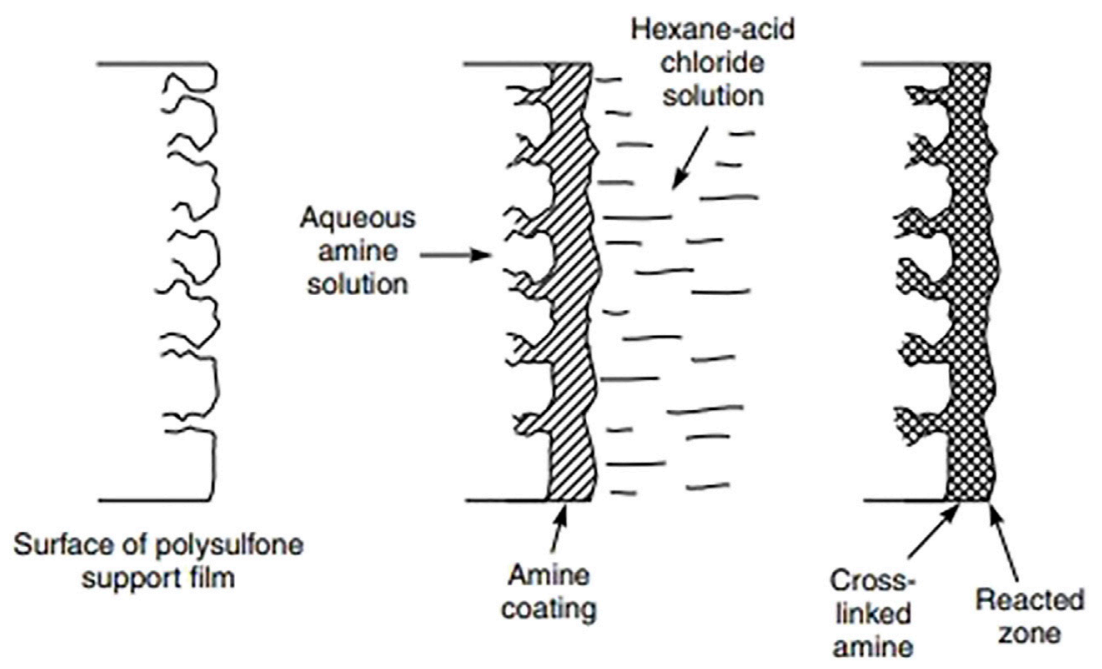

FIGURE 4 | Schematic of the interfacial polymerization process (Kim and Deng, 2011).

treatment of water and self-cleaning of surfaces. Its stability, ease of preparation and commercial availability add to its functionality (Mills and Le Hunte, 1997; Paz, 2010). Rahimpour found that UV-irradiated $\mathrm{TiO}_{2} / \mathrm{PES}$ nanocomposite membranes had higher flux and improved fouling resistance compared to ordinary nanocomposite membranes, attributing the improvement to the photocatalysis and high hydrophilicity of $\mathrm{TiO}_{2}$ under $\mathrm{UV}$ irradiation (Rahimpour et al., 2008).

\subsection{Antimicrobial Activity}

Membrane biofouling, which is caused by microbial growth, has been a major challenge to membrane technology (Zhu et al., 2010). It increases energy costs, decreases permeability, and reduces permeate quality. Hence, developing antimicrobial membranes can result in significant enhancement in efficiency of the separation process. Silver (Ag), due to its impressive biocidal properties, is a highly explored antimicrobial agent and has proven applications in avenues such as antimicrobial coatings, plastics, and wound dressings (Liu 
TABLE 1 |Synthesis and properties of TFNs (Petersen, 1993; Kim et al., 2004; Louie et al., 2006; Ghosh and Hoek, 2009; Jadav and Singh, 2009; Zhou et al., 2009; Park K. T. et al., 2010; Li and Wang, 2010; Fathizadeh et al., 2011; Kim and Deng, 2011; Rana T. M. D. et al., 2011; Zhang et al., 2011; Lau et al., 2012; Huang et al., 2013a; Kim E. S. et al., 2013; Alam et al., 2013; Baroña et al., 2013; Chan et al., 2013; Pendergast et al., 2013; Shen et al., 2013 ; Hermans et al., 2014; Zhao et al., 2014; Ghanbari et al., 2015; Hermans et al., 2015; Safarpour et al., 2015; Shenvi et al., 2015).

\begin{tabular}{|c|c|c|c|c|}
\hline Polymer matrix & Nanoparticle & Synthesis method & Properties & References \\
\hline Polyamide(MPD-TMC) & Zeolite A (NaA) (50-150 nm) & IP with zeolite LTA in TMC hexane & $\begin{array}{l}\text { Smoother, more hydrophillic, higher water } \\
\text { permeability with equivalent salt rejection }\end{array}$ & $\begin{array}{l}\text { Li and Wang, } \\
\text { (2010) }\end{array}$ \\
\hline Polyamide(MPD-TMC) & Zeolite A (NaA) $(100,200,300$ nm) & $\begin{array}{l}\text { IP with aeolite LTA in TMC- } \\
\text { isoparaffin }\end{array}$ & $\begin{array}{l}\text { More permeable, negatively charged, } \\
\text { thicker than PA TFC films }\end{array}$ & $\begin{array}{l}\text { Li and Wang, } \\
\text { (2010) }\end{array}$ \\
\hline Polyamide(MPD-TMC) & Zeolite $\mathrm{A}(\mathrm{NaA}$ or $\mathrm{AgA})(140 \mathrm{~nm})$ & IP with zeolite A in TMC isoparaffin & $\begin{array}{l}\text { High water permeability, smooth interface, } \\
\text { limited bactericidal activity for AgA } \\
\text { membranes }\end{array}$ & $\begin{array}{l}\text { Li and Wang, } \\
\text { (2010) }\end{array}$ \\
\hline Polyamide(MPD-TMC) & Zeolite A(NaA) $250 \mathrm{~nm}$ & IP with zeolite A in TMC-isoparaffin & $\begin{array}{l}\text { Different post treatmentchanging the } \\
\text { molecular structure, commercially relevant } \\
\text { RO separation }\end{array}$ & $\begin{array}{l}\text { Li and Wang, } \\
(2010)\end{array}$ \\
\hline Polyamide(MPD-TMC) & $\begin{array}{l}\text { Commercial Silica nanoparticles } \\
\text { LUDOX HS-4O(16 nm) and TEOS } \\
\text { hydrolyzedsilican }(3 \mathrm{~nm})\end{array}$ & $\begin{array}{l}\text { IP with adding silican in MPD } \\
\text { aqueous solution }\end{array}$ & $\begin{array}{l}\text { Tunable pore radius, increasing number of } \\
\text { pores, higher thermal stability, high water } \\
\text { flux and low salt rejection }\end{array}$ & $\begin{array}{l}\text { Li and Wang, } \\
\text { (2010) }\end{array}$ \\
\hline Polyamide (MPD-BTC) & $\begin{array}{l}\text { Commercial silver nanoparticles } \\
(50-100 \mathrm{~nm})\end{array}$ & IP with adding silver in BTC-HCFC & $\begin{array}{l}\text { Slightly lower flux and higher rejection, } \\
\text { higher antibiofouling effect }\end{array}$ & $\begin{array}{l}\text { Li and Wang, } \\
\text { (2010) }\end{array}$ \\
\hline Polyamide(MPD-TMC) & Synthesized $\mathrm{TiO}_{2}(\leq 10 \mathrm{~nm})$ & $\begin{array}{l}\text { Self assembly of } \mathrm{TiO}_{2} \text { on the neat } \\
\text { MPD-TMC TFC surface }\end{array}$ & $\begin{array}{l}\text { Higher salt rejection and lower flux, higher } \\
\text { photocatalyticbatericidal efficiency under } \\
\text { UV light }\end{array}$ & $\begin{array}{l}\mathrm{Li} \text { and Wang, } \\
(2010)\end{array}$ \\
\hline Polyamide(MPD-TMC) & Commercial $\mathrm{TiO}_{2}(30 \mathrm{~nm})$ & IP with adding $\mathrm{TiO}_{2}$ in $\mathrm{TMC}-\mathrm{HCFC}$ & $\begin{array}{l}\text { Enhanced surface hydrophilicity, } \\
\text { comparable water flux and higher salt } \\
\text { rejection with limited amount of } \mathrm{TiO}_{2}\end{array}$ & $\begin{array}{l}\text { Li and Wang, } \\
\text { (2010) }\end{array}$ \\
\hline Polyamide(MPD－TMC) & $\begin{array}{l}\text { Commercial MWCNT(dia: } \\
\text { 9-12 nm; length: 10-15 um) }\end{array}$ & $\begin{array}{l}\text { IP with adding MWCNTs in MPD } \\
\text { aq. solution }\end{array}$ & $\begin{array}{l}\text { Slightly lower salt rejection and flux; } \\
\text { improved chlorine resistance with } \\
\text { increase in MWCNT loading }\end{array}$ & $\begin{array}{l}\text { Zhang et al. } \\
\text { (2011) }\end{array}$ \\
\hline Polyamide(MPD-TMC) & 250 nm Linde Type-A zeolite & $\begin{array}{l}\text { IP with adding Zeolite A in aq. } \\
\text { solution of MPD, TEA, CSA, } \\
\text { SLS, IPA }\end{array}$ & $\begin{array}{l}\text { (1) Smoother, more hydrophilic surfaces } \\
\text { (2) higher water permeability and salt } \\
\text { rejection, and (3) improved resistance to } \\
\text { physical compaction }\end{array}$ & $\begin{array}{l}\text { Pendergast } \\
\text { et al. (2013) }\end{array}$ \\
\hline $\begin{array}{l}\text { Sulfonated poly(arylene ether } \\
\text { sulfone) - polyamide (MPD-TMC) } \\
\text { copolypmer }\end{array}$ & $\begin{array}{l}\text { Synthesized mesoporous silica } \\
\text { nanoparticles (100 nm) }\end{array}$ & $\begin{array}{l}\text { Interfacial polymerization with } \\
\text { adding } \mathrm{SiO}_{2} \text { in } \mathrm{TMC} \text {-cyclohexane }\end{array}$ & High water flux and similar salt rejection & $\begin{array}{l}\text { Park K. T. et al. } \\
(2010)\end{array}$ \\
\hline Polyamide(MPD-TMC) & $\begin{array}{l}\text { Polyamide single walled } \\
\text { aluminosilicate nanotubes }\end{array}$ & $\begin{array}{l}\text { Ip followed by reacting different } \\
\text { imogolite concentrations in } 0.01 \% \\
\text { (w/v) TMC-hexane solution with the } \\
\text { top surface of the MPD-soaked } \\
\text { membrane }\end{array}$ & $\begin{array}{l}\text { The hydrophilicity was increased as } \\
\text { observed in the enhancement in water flux } \\
\text { and pure water permeance, due to the } \\
\text { presence of hydrophilic nanotubes. With } \\
\text { the incorporation of the single-walled } \\
\text { aluminosilicate nanotubes, higher } \\
\text { permeate flux was achieved while } \\
\text { sustaining high rejection of monovalent } \\
\text { and divalent ions }\end{array}$ & $\begin{array}{l}\text { Baroña et al. } \\
\text { (2013) }\end{array}$ \\
\hline Polyamide(MPD-TMC) & NanozeoliteNaX & $\begin{array}{l}\text { IP over PES support. Immersed in } \\
\text { aq MPD and then } n \text {-hexane soln } \\
\text { of TMC }\end{array}$ & $\begin{array}{l}\text { The results showed improvement of } \\
\text { surface properties such as RMS } \\
\text { roughness, contact angle and solid-liquid } \\
\text { interfacial free energy, a decrease in film } \\
\text { thickness and an increase in pore size and } \\
\text { water flux }\end{array}$ & $\begin{array}{l}\text { Fathizadeh } \\
\text { et al. (2011) }\end{array}$ \\
\hline Polyamide(MPD-TMC) & HNT & $\begin{array}{l}\text { IP by pouring MPD over PES } \\
\text { Support. TMC solutions in } \\
\text { cyclohexane then added to the } \\
\text { substrate }\end{array}$ & $\begin{array}{l}\text { Shows increase in hydrophilicity, surface } \\
\text { roughness and water flux. Higher loading } \\
\text { of HNT results in increase in flux, but } \\
\text { decrease in salt rejection }\end{array}$ & $\begin{array}{l}\text { Ghanbari et al. } \\
\text { (2015) }\end{array}$ \\
\hline Polyamide(MPD - TMC) & silicalite-1 nanozeolite & $\begin{array}{l}\text { IP carried out between semi- } \\
\text { aligned functionalised CNTs over } \\
\text { PES support. Immersed in aq MPD } \\
\text { and non aq TMC. }\end{array}$ & $\begin{array}{l}\text { Excellent permeability and chemical } \\
\text { stability }\end{array}$ & $\begin{array}{l}\text { Huang et al. } \\
(2013 a)\end{array}$ \\
\hline Polyamide(MPD-TMC) & zwitterion functionalized CNT & $\begin{array}{l}\text { IP over PES support. Immersed in } \\
\text { aq MPD and then } n \text {-hexane soln } \\
\text { of TMC }\end{array}$ & Increased salt rejection and flux & $\begin{array}{l}\text { Chan et al. } \\
\text { (2013) }\end{array}$ \\
\hline Polyamide(MPD-TMC) & $\begin{array}{l}\text { Modified carboxy-functionalized } \\
\text { MWNT }\end{array}$ & $\begin{array}{l}\text { IP over PES support. Immersed in } \\
\text { aq MPD and then } n \text {-hexane soln } \\
\text { of TMC }\end{array}$ & $\begin{array}{l}\text { Increasing loading showed increase in flux } \\
\text { without significant decrease in salt } \\
\text { rejection. Improvement in antifouling and } \\
\text { antioxidative properties }\end{array}$ & $\begin{array}{l}\text { Zhao et al. } \\
(2014)\end{array}$ \\
\hline
\end{tabular}


TABLE 1 | (Continued) Synthesis and properties of TFNs (Petersen, 1993; Kim et al., 2004; Louie et al., 2006; Ghosh and Hoek, 2009; Jadav and Singh, 2009; Zhou et al., 2009; Park K. T. et al., 2010; Li and Wang, 2010; Fathizadeh et al., 2011; Kim and Deng, 2011; Rana T. M. D. et al., 2011; Zhang et al., 2011; Lau et al., 2012; Huang et al., 2013a; Kim E. S. et al., 2013; Alam et al., 2013; Baroña et al., 2013; Chan et al., 2013; Pendergast et al., 2013; Shen et al., 2013; Hermans et al., 2014; Zhao et al., 2014; Ghanbari et al., 2015; Hermans et al., 2015; Safarpour et al., 2015; Shenvi et al., 2015).

\begin{tabular}{|c|c|c|c|c|}
\hline Polymer matrix & Nanoparticle & Synthesis method & Properties & References \\
\hline Polyamide(MPD－TMC) & Reduced graphene oxide/ $/ \mathrm{TiO}_{2}$ & $\begin{array}{l}\text { IP over PES support. Immersed in } \\
\text { aq MPD and then } n \text {-hexane soln } \\
\text { of TMC }\end{array}$ & $\begin{array}{l}\text { Improved water permeability, salt } \\
\text { rejection, antifouling property, and } \\
\text { chlorine resistance by increasing } \\
\text { hydrophilicity, negative surface charge } \\
\text { and roughness of PA layer }\end{array}$ & $\begin{array}{l}\text { Safarpour } \\
\text { et al. (2015) }\end{array}$ \\
\hline Polyamide(PIP-TMC) & PMMA-MWNTs & $\begin{array}{l}\text { IP over PES support. Immersed in } \\
\text { aq PIP and thentoluenesoln } \\
\text { of TMC }\end{array}$ & - & $\begin{array}{l}\text { Shen et al. } \\
\text { (2013) }\end{array}$ \\
\hline NMP-PES & nano- $\mathrm{Fe}_{3} \mathrm{O}_{4}$ & $\begin{array}{l}\text { Solution dispersion blending } \\
\text { process and } \mathrm{PI}\end{array}$ & - & $\begin{array}{l}\text { Alam et al. } \\
\text { (2013) }\end{array}$ \\
\hline aPES/HBP & HBP-g-sillica & - & $\begin{array}{l}\text { enhanced the chlorine resistance of the } \\
\text { RO membrane, improved water } \\
\text { permeability }\end{array}$ & $\begin{array}{l}\text { Kim K. S. et al } \\
(2013)\end{array}$ \\
\hline
\end{tabular}

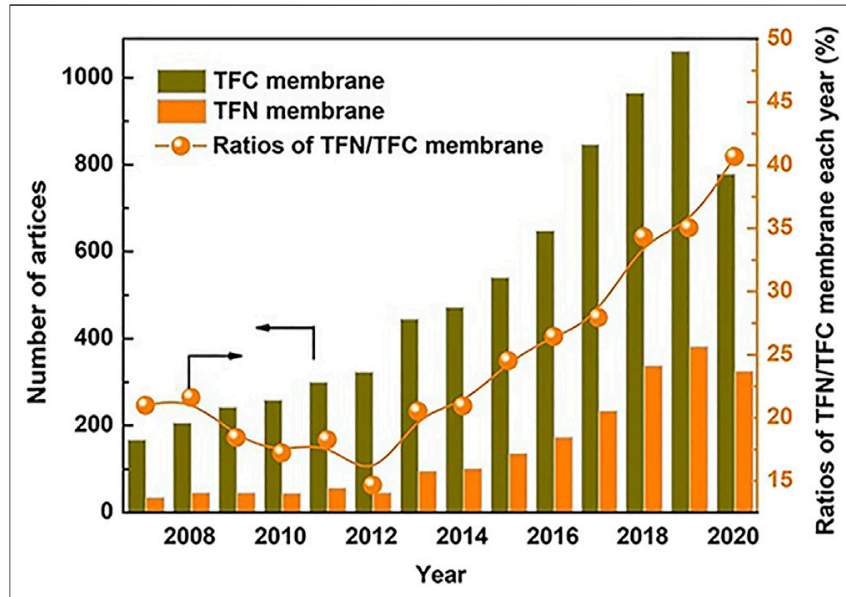

FIGURE 5 | Year wise Publication status of TFNs (Liao et al., 2021).

et al., 2008; Lind et al., 2009b). Addition of $\mathrm{Ag}_{2} \mathrm{O}$ nanoparticles not only acts as biocidal agent but also improves the desalination performance of the membrane (Al-Hobaib et al., 2015). Chou used Ag NPs in CA matrix and Zodrow incorporated Ag NPs into PSU matrix to improve biofouling resistance (Chou et al., 2005; Zodrow et al., 2009).Table 2 provides a summary of the variety of nanoparticles that are used in TFNs (Mills and Le Hunte, 1997; Chou et al., 2005; Liu et al., 2008; Rahimpour et al., 2008; Zodrow et al., 2009; Paz, 2010; Zhu et al., 2010; Daraei et al., 2012; Kim E. S. et al., 2013; Huang S. G. et al., 2013; Jamshidi Gohari et al., 2013; Duan et al., 2015a).The various performance parameters that are utilized in order to characterize TFNs have been discussed in detail in Section 6.

\section{TFN MEMBRANE PERFORMANCE CHARACTERISTICS}

Salt rejection and water flux are the two most important parameters that are used to judge the performance of
TFNs.Some of the most important membrane performance parameters have been discussed in the following subsections. These parameters depend upon many factors, some of which are surface roughness, hydrophilicity, surface charge density (Lu et al., 2013; Safarpour et al., 2015). The performance TFNs can be tailored as required by using different nanoparticles as fillers in the thin film, or by even using different methods to synthesize the membrane (Safarpour et al., 2015). Table 3 lists the different types of nanoparticles used as fillers in TFN membranes reported in literature. For each TFN, the water flux and salt rejection at a particular percentage loading of nanoparticles and the polymer matrix for the membrane is also reported. The last two membranes in Table 3 are exceptions, as they are not synthesized by IP method. Each of the following subsections deals with commonly used performance parameters.

\subsection{Water Flux}

The measurement of water flux in thin film nanocomposite membranes was performed using a cross-flow membrane module. The water flux was calculated using Equation 1:

$$
\mathrm{F}=\mathrm{V} /(\mathrm{At}) \text {, }
$$

Where $\mathrm{F}$ is the pure water flux, $\mathrm{V}$ is total volume of permeated pure water, $\mathrm{A}$ is area of the membrane, and $\mathrm{t}$ is the operation time (Wu et al., 2010).

Nanoparticles in the thin film membrane can lead to an increase in hydrophilic nature and decrease in cross-linking of the membrane which consequently contributes to high flux of water through the membrane. Increased water flux can also depend upon the structure of the nanoparticle used. For example, MCM-41 silica nanoparticles are porous in nature (Yin et al., 2012). These pores inside the nano-particles present in the thin film membrane can act as short pathways for preferential passage of water molecules through the nanoparticle (Yin et al., 2012). Water tends to move faster through hydrophobic porous particles than hydrophilic nonporous particles (Duan et al., 2015b).The nanomaterials 
TABLE 2 | Summary of nanoparticles used in TFNs (Fathizadeh et al., 2011; Daraei et al., 2012; Huang et al., 2013a; Kim E. S. et al., 2013; Alam et al., 2013; Baroña et al., 2013; Huang et al., 2013b; Chan et al., 2013; Shen et al., 2013; Zhao et al., 2014; Ghanbari et al., 2015; Safarpour et al., 2015).

\begin{tabular}{|c|c|c|c|}
\hline Nanoparticle & Aqueous phase & Salt in feed & $\begin{array}{l}\text { Applied } \\
\text { pressure(psi) }\end{array}$ \\
\hline multiwalled cnt; <8 nm diameter & MPD 2\%wt & $\mathrm{NaCl} 1,000 \mathrm{ppm}$ & 100 \\
\hline $\begin{array}{l}\text { halogen reactive, nitrogen from amines, imides, } \\
\text { sulfonamides }\end{array}$ & MPD 4\%wt & - & - \\
\hline Zeolite A $(0.4 \% \mathrm{w} / \mathrm{v})$ (in organic phase) & MPD 2\%wt & $\mathrm{NaCl} 2,000$ ppm & 180 \\
\hline Linde type $A(L T A)$ zeolite nanocrystals & $\begin{array}{l}\text { MPD(2-3\% w/v) TEACSA(6\% w/v) SLS(0.02\% w/v) IPA } \\
(0-29 \% \text { w/v) }\end{array}$ & $\mathrm{NaCl} 2,000$ ppm & 224.8 \\
\hline TiO2(in organic phase) & MPD (2\%wt) NaOH(0.05wt\%) & $\mathrm{MgSO}_{4} 2,000 \mathrm{ppm}$ & 87 \\
\hline Ag nanoparticles & $\mathrm{MPD}(2 \% w t) \mathrm{NaOH}$ & $\mathrm{MgSO}_{4} 2,000 \mathrm{ppm}$ & $125-250$ \\
\hline $0.2 \mathrm{w} / \mathrm{w} \%$ zeolite-A nanoparticles in the TMC solution & $\begin{array}{l}\text { MPD( } 2 \% \text { w/v) TEA(2\%)CSA(4\% w/v) SLS(0.02\% w/v) IPA } \\
(10 \% \mathrm{w} / \mathrm{v})\end{array}$ & $\mathrm{NaCl} 10 \mathrm{mM}$ soln & 225 \\
\hline $\begin{array}{l}\text { Polyhedral Oligomeric Silsequioxane(POSS) (in } \\
\text { organic phase) }\end{array}$ & $\mathrm{MPD}(2 \mathrm{wt} \%)$ & $\mathrm{NaCl} 2,000$ ppm & 225 \\
\hline \multicolumn{4}{|l|}{ Oxidized MWNT } \\
\hline AluminoSilicate SWNT & - & $\begin{array}{l}\mathrm{NaCl} \text { and } \mathrm{MgSO}_{4} 2,000 \text { ppm } \\
\text { each }\end{array}$ & - \\
\hline nanozeolite $\mathrm{NaX}$ & MPD & - & 175 \\
\hline HNT & MPD $2 \% w / v$ & $\mathrm{NaCl} 2,000$ ppm & 218 \\
\hline silicalite-1 nanozeolites & MPD $2 \% \mathrm{w} / \mathrm{v}$ & - & - \\
\hline zwitterion functionalised CNT & MPD $2 \% \mathrm{w} / \mathrm{v}$ & $\mathrm{NaCl} 1,000 \mathrm{ppm}$ & 530 \\
\hline Modified carboxy-functionalised MWNT & MPD $2 \% \mathrm{w} / \mathrm{v}$ & $\mathrm{NaCl} 2,000 \mathrm{ppm}$ & 232 \\
\hline Reduced graphene oxide/ $/ \mathrm{TiO}_{2}$ & MPD 2\%wt & $\mathrm{NaCl} 2,000$ ppm & 218 \\
\hline PMMA-MWNTs & PIP & $\mathrm{NaCl} 2,000$ ppm & 145 \\
\hline nano $\mathrm{Fe}_{3} \mathrm{O}_{4}$ & NMP & - & - \\
\hline mesoporous $\mathrm{SiO}_{2}$ nano-particles & sulfonated poly(arylene ether sulfone) & $\mathrm{NaCl} 2,000 \mathrm{ppm}$ & 225 \\
\hline HBP-g-silica & aPES-MPDA-TEA & - & - \\
\hline nano $\mathrm{ZnO}$ & MPD(2\%)-TMC(0.1\%) & - & - \\
\hline
\end{tabular}

possess high surface porosity resulting in improved salt rejection capacity and reduced macro void formation.

Carbon nanotubes also facilitate high flux of water, as they act like channels for transportation of water (Safarpour et al., 2015). This reduces the water transport route as the water molecules can enter into part of the multiwalled carbon nanotubes (MWCNTs) instead of passing through the entire PA film. Aggregation of these nanoparticles might also lead to the formation of a network inter-connected with other pores in the membrane leading to a higher increase in water flux (Zhang et al., 2011).

\subsection{Salt Rejection}

For all the data reported, salt rejection is calculated using the formula:

$$
\mathrm{R}=1-\mathrm{C}_{\mathrm{p}} / \mathrm{C}_{\mathrm{f}}
$$

Where $\mathrm{R}$ is salt rejection, $\mathrm{C}_{\mathrm{p}}$ is concentration of salt in the permeate solution, and $\mathrm{C}_{\mathrm{f}}$ is concentration of salt in the feed solution (Wu et al., 2010).

Salt rejection is governed by factors such as defects and molecular sieving. Also, it is known that for transport of ions of different valences through carbon channels with negatively charged functional groups, ion exclusion depends more upon electrostatic interactions (Donnan exclusion) rather than steric hindrance (Shen et al., 2013). It is also known that high crosslinking in the MPD-TMC (m-phenylene diamine-trimesoyl chloride) layer causes higher salt rejection and lowerNaClpermeance (Duan et al., 2015b).
As reported by Safarpour, increase in $\mathrm{rGo} / \mathrm{TiO}_{2}$ loading in thin film membrane leads to decrease in roughness of membrane (Safarpour et al., 2015). This is due to the increase in hydrogen bonding between the hydrophilic nanoparticles and polyamide layer. It was also observed that increase in nanoparticle loading causes decrease in contact angle with water, which is an indication of increasing hydrophilicity of membrane. This can be understood based on the increase of surface charge density. Another trend observed is how the pure water flux increases with the increase in nanoparticle loading. This is expected as an increase in hydrophilicity leads to increased flux (Safarpour et al., 2015).

\subsection{Selectivity Versus Permeability}

Permeability and selectivity are two major performance factors for membrane technology. In improving the performance of membranes, there is always a trade-off between these two factors. In an attempt to achieve high levels of water flux, a decrease in salt rejection is obtained. For example, work done by Jun Yin shows a large trade-off between flux and salt rejection (Yin et al., 2012). Pure water flux increases with percentage loading of MWCNTs, from $20 \mathrm{LMH}$ at zero loading of MWCNTs to $71 \mathrm{LMH}$ at $0.1 \% \mathrm{w} / \mathrm{v}$ of MWCNTs. Salt rejection is observed to decrease with increase in loading of MWCNTs, from $94 \%$ at zero loading of MWCNTs to $82 \%$ at $0.1 \% \mathrm{w} / \mathrm{v}$ of MWCNTs.

The incorporation of nanomaterials could alter the physicochemical properties of the membrane such as cross 
TABLE 3 | Water flux and NaCl rejection at given loading of nanoparticle fillers in TFN membranes (Fathizadeh et al., 2011; Daraei et al., 2012; Huang et al., 2013a; Kim E. S. et al., 2013; Alam et al., 2013; Baroña et al., 2013; Huang et al., 2013b; Chan et al., 2013; Shen et al., 2013; Zhao et al., 2014; Ghanbari et al., 2015; Safarpour et al., 2015).

\section{Filler}

\section{Polymer matrix(for membranes manufactured by IP)}

\section{Zeolite particles(NaA)}

Linde type A-1 (NaA)

AgA

MWNT (conventional process)

MWNT (improved process)

Ag20 (max - flux condition)

Ag20 (max - rejection condition)

$\mathrm{MgTiO} 3$

$\mathrm{Al} 2 \mathrm{O} 3$

Aluminosilicate single walled nanotubes

HNT (max flux)

HNT (max rejection)

CNT

Silica (mcm-41) nanoparticles (max flux)

Silica (mcm-41) nanoparticles (max rejection)

non porous spherical silica nps (max flux)

non porous spherical silica nps (max rejection)

Zwitter ion functionalised CNTs (max flux)

Carboxy functionalised MWNTs (max flux)

Reduced graphene oxide/TiO2

PMMA-MWNT

POSS-1 (max flux)

POSS-2 (max flux)

POSS-3 (max flux)

POSS-4 (max flux)

ZIF-8 (max flux)

ZIF-8 (max rejection)

acidified MWCNT (max flux)

acidified MWCNT (max salt rejection)

Nano-ZnO

nano-Fe3O4 (max flux condition)

nano-Fe3O4 (max rejection condition)

$\begin{array}{lc}\text { MPD-TMC } & 0.4(\mathrm{w} / \mathrm{v}) \\ \text { MPD-TMC } & 0.2(\mathrm{w} / \mathrm{v}) \\ \text { MPD-TMC } & 0.4(\mathrm{w} / \mathrm{v}) \\ \text { TEOA-TMC } & 0.05(\mathrm{w} / \mathrm{v}) \\ \text { TEOA-TMC } & 0.05(\mathrm{w} / \mathrm{v}) \\ \text { MPD-TMC } & 0.03(\mathrm{wt}) \\ \text { MPD-TMC } & 0.03(\mathrm{wt}) \\ \text { MPD-TMC } & 0.1(\mathrm{wt}) \\ \text { MPD-TMC } & 1 \mathrm{wt} \\ \text { MPD-TMC } & 0.59 \mathrm{wt} \\ \text { MPD-TMC } & 0.1(\mathrm{w} / \mathrm{v}) \\ \text { MPD-TMC } & 0.05(\mathrm{w} / \mathrm{v}) \\ \text { MPD-TMC } & 0.1(\mathrm{w} / \mathrm{v}) \\ \text { MPD-TMC } & 0.05(\mathrm{wt}) \\ \text { MPD-TMC } & 0.1(\mathrm{wt}) \\ \text { MPD-TMC } & 0.1(\mathrm{wt}) \\ \text { MPD-TMC } & 0.05(\mathrm{wt}) \\ \text { MPD-TMC } & 20 \mathrm{wt} \\ \text { MPD-TMC } & 0.1(\mathrm{wt}) \\ \text { MPD-TMC } & 0.02(\mathrm{wt}) \\ \text { PIP-TMC } & 0.67 \mathrm{~g} / \mathrm{L} \\ \text { MPD-TMC } & 0.4 \mathrm{w} / \mathrm{v} \\ \text { MPD-TMC } & 0.4 \mathrm{w} / \mathrm{v} \\ \text { MPD-TMC } & 0.4 \mathrm{w} / \mathrm{v} \\ \text { MPD-TMC } & 0.4 \mathrm{w} / \mathrm{v} \\ \text { MPD-TMC } & 0.4(\mathrm{w} / \mathrm{v}) \\ \text { MPD-TMC } & 0.1(\mathrm{w} / \mathrm{v}) \\ \text { MPD-TMC } & 0.1(\mathrm{w} / \mathrm{v}) \\ \text { MPD-TMC } & 0.1(\mathrm{w} / \mathrm{v}) \\ \text { MPD-TMC } & 0.5 \mathrm{wt} \% \\ \text { PES dissolved in NMP (not by IP) } & 15(\mathrm{wt}) \\ \text { PES dissolved in NMP (not by IP) } & 10(\mathrm{wt}) \\ & \end{array}$

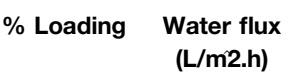

Salt rejection (\%)

Salt solution

Pressure psi

$92.0 \pm 1.9 \quad \mathrm{NaCl} 2,000 \mathrm{ppm}$

$92.0 \pm 0.5 \quad \mathrm{NaCl} 2,000 \mathrm{ppm}$

$93.5 \pm 1 \quad \mathrm{NaCl} 2,000 \mathrm{ppm}$

Not reported N/A

Not reported N/A

$99 \pm 0.1 \quad \mathrm{NaCl} 2,000 \mathrm{ppm}$

$99 \pm 0.1 \quad \mathrm{NaCl} 2,000 \mathrm{ppm}$

$98 \quad \mathrm{NaCl} 2,000 \mathrm{ppm}$

$88 \mathrm{NaCl} 2,000 \mathrm{ppm}$

96.24

$80 \pm 3$

$95 \pm 2$

90

97.9

$98.9 \pm 3$

$97.6 \pm 2$

$98.1 \pm 2$

98.6

90

99.45

44.1

$98.2 \pm 0.3$

$98.9 \pm 0.2$

$98.6 \pm 0.3$

$95.9 \pm 0.6$

$98.5 \pm 0.3$

$99.2 \pm 0.4$

82

94

98

39

68
$0.034 \mathrm{M}$

$\mathrm{NaCl}$ 2,000 ppm

$\mathrm{NaCl}$ 2,000 ppm

$\mathrm{NaCl} 2,000$ ppm

$\mathrm{NaCl}$ 2,000 ppm

$\mathrm{NaCl} 2,000$ ppm

$\mathrm{NaCl}$ 2,000 ppm

$\mathrm{NaCl}$ 2,000 ppm

$\mathrm{NaCl} 1,000$ ppm

$\mathrm{NaCl} 2,000$ ppm

$\mathrm{NaCl}$ 2,000 ppm

$\mathrm{NaCl}$ 2,000 ppm

$\mathrm{NaCl}$ 2,000 ppm

$\mathrm{NaCl} 2,000$ ppm

$\mathrm{NaCl}$ 2,000 ppm

$\mathrm{NaCl}$ 2,000 ppm

$\mathrm{NaCl} 2,000$ ppm

$\mathrm{NaCl}$ 2,000 ppm

$\mathrm{NaCl} 2,000$ ppm

$\mathrm{NaCl}$ 2,000 ppm

Not reported

$\mathrm{NaCl}$ 2,000 ppm $\mathrm{NaCl}$ 2,000 ppm

179
224.8
225
87
87
225
225
225
145
232
218
218
232
290
305
319
334
530
232
218
145
225
225
225
225
225
225
232
232
225
145
145

linkage, charge density and hydrophilicity. This provides specific water pathways that could conquer the permeability-selectivity trade-off. These facts are evident by the advantage of polydopamine coating that provides ZIF-8 nanoparticles with dispersibility in water (You et al., 2021) and other recent works on TFN membranes (Jeon and Lee, 2020; Saleem and Zaidi, 2020; Siew Khoo et al., 2021). Such TFN membranes exhibited improved permeability in desalination.

Almost all studies that used hydrophilic nanofillers showed a decreased contact angle in the TFNs, proving improved surface hydrophilicity. With increase in zeolite loading from 0 to $0.4 \%$ (w/ v) the contact angle of zeolite-PA TFN membrane has been seen to decrease from around $70^{\circ}$ to $40^{\circ}$ (Jeong et al., 2007). Other examples of oxidized MWNTs-PA TFN membranes and silicaPA TFN membranes have also displayed a significant reduction in contact angle with increase in loading up to certain specific values (Zhang et al., 2011; Yin et al., 2012). This indicates enhanced water permeability with an increase in nanofiller loading.

Two possible explanations have been proposed for the decrease in the contact angle due to the nanoparticles (NPs). The first ascribes the increased surface hydrophilicity to the hydrolysis of acyl chloride resulting in the generation of carboxylic acid functional groups. This phenomenon occurs due to increasedcount of surface acyl chloride groups in TMC that remain without reacting with the dimethyl pimelimidate's (DMP) amine group as a result of NPs hydrating and releasing heat when in contact with the MPD aqueous solution (Kim et al., 2000; Ghosh et al., 2008). The second suggests that the presence of embedded hydrophilic NPs on the membrane surface offers larger number of hydrophilic functional groups to the surface.

Along with hydrophilicity, the thickness and the cross-linkage condition of the thin-film layer are key factors in determining the water permeability and selectivity (Ghosh et al., 2008). Generally, a lesserextent of cross-linking and thinner films offer higher permeability. Incorporation of NPs in the PA matrix could reduce cross-linking in the thin-film layer by disrupting the reaction between amine groups and acyl chloride groups. Lind showed through FTIR and XPS results that the cross lining in all their TFN membranes were less compared to the corresponding TFC membranes (Lind et al., 2010). However, it was put forward that molecular sieving or defects could have played an importantpart in the performance.

Furthermore, the inclusion of NPs may also produce additional channels for the flow of water while excluding the 


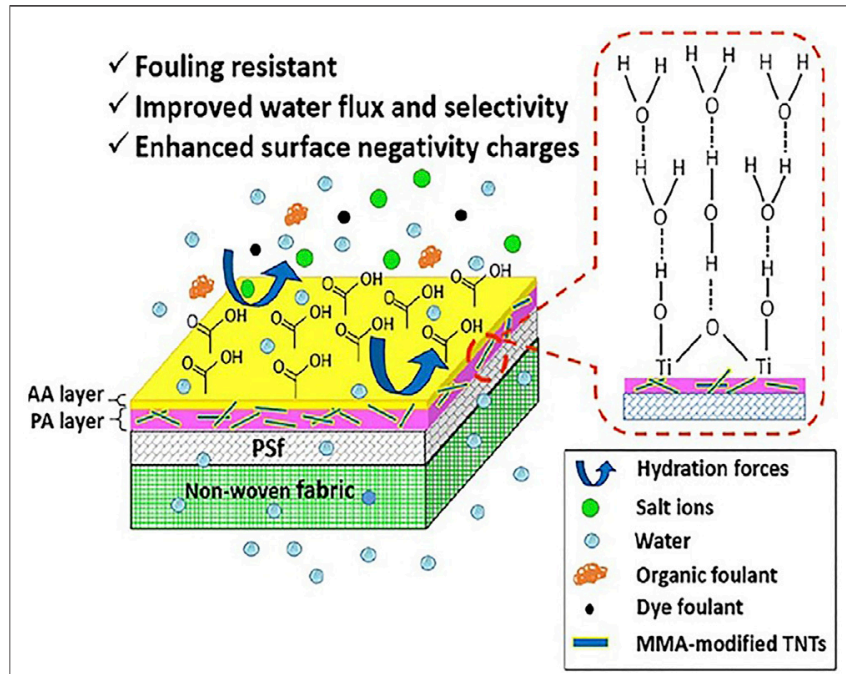

FIGURE 6 | Improved antifouling behaviour through AA-modified TFN membrane (Siew Khoo et al., 2021).

solutes. A higher value of water flux with constant salt rejection in zeolite-A NP TFNs was reported by Jeong(Jeong et al., 2007). The hydrophilic molecular sieving NPs may provide preferential flow paths for water molecules. Yin showed that mesoporous silica NPs with highly ordered hexagonal pores exhibit higher permeability compared to nonporous silica NPs (Yin et al., 2012). The nonporous silica NPs resulted in cross linking thereby increasing permeability compared to regular TFCs. The increase in permeability was even higher for the mesoporous silica NP TFNs.

It is desired to significantly improve permeability while maintaining the same salt rejection. However, in order to exploit the favorable properties of the NPs, it is necessary to optimize the internal structure, size and surface properties while ensuring suitable interfacial interactions with the polymer.

\subsection{Antifouling}

Extensive research has been conducted on incorporating nanoparticles that reduce the fouling of membranes, hence prolonging the duration for which the membrane can be used. It is known that the antifouling ability is related to the hydrophilic nature, negative charge and smoothness of the membrane (Shen et al., 2013). The anti-fouling performance of membranes can be evaluated by conducting filtration experiments. The membrane is first compacted using distilled water. This ensures that an almost constant permeate flux is obtained. This is necessary as the initial flux affects the extent of fouling. A protein solution, for example BSA (bovine serum albumin) that possesses synergistic fouling effects, is then taken in the reservoir in order to conduct the permeating experiment for a definite time period. The fouling capacity is measured based on the decline in the flux with time (Shen et al., 2013).

The incorporation of hydrophilic NPs into the PA structure has been shown to increase hydrophilicity of the surface and usually helps diminish surface fouling. Long term fouling tests with silica particles, chloroform, and sodium humate have shown TFN membranes to have a much lower flux reduction when compared to TFC membranes (Rana D. et al., 2011). Extensive research work has been conducted to investigate the antifouling ability of TFNas shown in Figure 6 (Safarpour et al., 2015; Siew Khoo et al., 2021). In order to compare the antifouling properties, water flux through a pristine RO membrane was compared to flux through a TFN with $0.02 \%$ wt. loading of $\mathrm{rGo} / \mathrm{TiO}_{2}$ under the same applied pressure. The flux through the former dropped to $49 \%$ of its value whilst the flux through later decreased to $75 \%$ of its value after $180 \mathrm{~min}$ of filtration (Safarpour et al., 2015). Hence the presence of fillers in thin film membrane leads to better antifouling resistance. Similarly, recent reports show how the introduction of carboxyl-functionalized MWCNTs reduces fouling (Zhao et al., 2014). This has been attributed to the negative surface charge and greater surface hydrophilicity (Lau et al., 2015).

\subsection{Chlorine Resistance}

Polyamide (PA) based membranes do not have a good resistance to continuous exposure of oxidizing agents. Chlorine is widely used as disinfectant in water treatment (Park et al., 2008). However, chlorine is also a strong oxidizing agent and feed water coming to membrane units from disinfection plants contains chlorine. PA membranes cannot tolerate water having chlorine even in the order of few parts per billion, and the chlorine treatment is required to check the development of biofilms on the membrane. Removing the chlorine from water is an undesired option as this will increase the number of treatment steps, and the overall cost of water treatment. Hence there is a need to increase the resistance of membranes to chlorine (Lau et al., 2015). In order to study the chlorine resistance of a membrane, it is subjected to a high concentration of free chlorine for a short time, which is essentially analogous to the exposure of the membrane for a long time to free chlorine of low concentration (Shen et al., 2013). In order to conduct this study, chlorinate solution is prepared and, the water flux and salt rejection of the required membrane, before and after chlorination is measured and compared (Shen et al., 2013).

As reported by Safarpour et al. (2015), salt rejections before and after exposure to sodium hypochlorite for pristine membrane and TFN were compared to study the chlorine resistance (Safarpour et al., 2015). The bare membrane (without any modifications) showed a decrease in salt rejection from 95.4 to $65.38 \%$, while the TFN membrane with $0.02 \%$ loading of $\mathrm{rGo} /$ $\mathrm{TiO}_{2}$ showed decrease from 99.45 to $96.4 \%$ (Safarpour et al., 2015).

Exposure to chlorine can cause ring-chlorination and $\mathrm{N}$-chlorination reactions which disrupt the symmetry of the PA layer converting it from a crystalline state to an amorphous one (Safarpour et al., 2015). This leads to larger free volumes and flexibility of the PA layer that allow salt molecules to pass through easily. On the other hand, the intermolecular hydrogen bonds are amplified by interaction between $\mathrm{rGo} / \mathrm{TiO}_{2}$ particles and membrane active layer (Safarpour et al., 2015). This can provide obstruction to the substitution of hydrogen with chlorine on the amide groups of 
TABLE 4 | Summary of TFNs and their composition, performance, fabrication and applications.

\begin{tabular}{|c|c|c|c|c|c|c|c|}
\hline \multicolumn{2}{|l|}{ TFN } & \multirow[t]{2}{*}{ Particle size } & \multirow{2}{*}{$\begin{array}{l}\text { Loading wt } \%(b e s t \\
\text { performance) }\end{array}$} & \multirow{2}{*}{$\begin{array}{l}\text { Fabrication } \\
\text { method }\end{array}$} & \multirow[t]{2}{*}{ Application } & \multirow[t]{2}{*}{ Performance } & \multirow[t]{2}{*}{ References } \\
\hline Filler & Polymer & & & & & & \\
\hline Oxidized MWNTs & $\begin{array}{l}\text { Pebax } 1074 \\
\text { or PVA }\end{array}$ & $\begin{array}{l}\text { OD:20-40 nm; } \\
\mathrm{L}: 5-15 \mu \mathrm{m}\end{array}$ & $\begin{array}{l}\text { 0-20\% of } \\
\text { polymer(10\% of PVA) }\end{array}$ & $\begin{array}{l}\text { Coating + solvent } \\
\text { evaporation }\end{array}$ & $\begin{array}{l}\text { Water/oil } \\
\text { emulsion } \\
\text { separation }\end{array}$ & $\begin{array}{l}\text { Under } 100 \text { psi, optimal } \\
\text { water flux is } 330 \mathrm{~L} / \mathrm{m} 2 \mathrm{~h} \text {, } \\
\text { organic solute rejection is } \\
99.8 \% \text {; Fouling } \\
\text { resistance } \uparrow\end{array}$ & $\begin{array}{l}\text { Wang et al. } \\
(2005)\end{array}$ \\
\hline Zeolite(NaA) & PA & $50-150 \mathrm{~nm}$ & $\begin{array}{l}0.004-0.4 \%(w / v) \text { in } \\
\text { organic phase }\end{array}$ & $\mathrm{IP}$ & $\mathrm{RO}$ & $\begin{array}{l}\text { Surface hydrophilicity } \uparrow \text {; } \\
\text { Pw } \uparrow ; \text { Salt rejection no } \\
\text { change; New } \\
\text { concept: TFN }\end{array}$ & $\begin{array}{l}\text { Jeong et al. } \\
(2007)\end{array}$ \\
\hline Ag NPs & PA & $50-100 \mathrm{~nm}$ & $\begin{array}{l}10 \% \text { of polymer in } \\
\text { organic phase }\end{array}$ & $\mathrm{IP}$ & $N F$ & $\begin{array}{l}\text { Water flux and salt } \\
\text { rejection no change; Good } \\
\text { antibiofouling property }\end{array}$ & $\begin{array}{l}\text { Lee et al. } \\
(2007)\end{array}$ \\
\hline TiO2 (P25) & PA & $30 \mathrm{~nm}$ & $\begin{array}{l}1.0-9.0 \%(5.0 \%) \\
\text { organic phase }\end{array}$ & $\mathrm{IP}$ & $N F$ & $\begin{array}{l}\text { Under } 87 \text { psi, optimal } \\
\text { water flux is } 9.1 \mathrm{~L} / \mathrm{m} 2 \mathrm{~h} \text {, } \\
\mathrm{MgSO}_{4} \text { rejection }(95 \% \text {, } \\
2000 \mathrm{mg} / \mathrm{L})\end{array}$ & $\begin{array}{l}\text { Lee et al. } \\
\text { (2008) }\end{array}$ \\
\hline $\begin{array}{l}\text { Silica(LUDOX } \\
\text { HS-40) }\end{array}$ & PA & $13.2 \mathrm{~nm}$ & $5-28 \%$ of $\mathrm{PA}$ & $\mathbb{I P}$ & $\begin{array}{l}\text { Dioxane } \\
\text { solution } \\
\text { filtration }\end{array}$ & Pw $\uparrow$; Solute rejection $\downarrow$ & $\begin{array}{l}\text { Singh and } \\
\text { Aswal, (2008) }\end{array}$ \\
\hline $\begin{array}{l}\text { Zeolite (NaA } \\
\text { and } \mathrm{AgA})\end{array}$ & PA & $50-250 \mathrm{~nm}$ & $\begin{array}{l}0.4 \%(\mathrm{w} / \mathrm{v}) \text { in organic } \\
\text { phase }\end{array}$ & $\mathrm{IP}$ & $\mathrm{RO}$ & $\begin{array}{l}\text { Pw } \uparrow \text {; Salt rejection no } \\
\text { change; AgA-TFN } \\
\text { membranes exhibited } \\
\text { more hydrophilic and } \\
\text { smooth surfaces }\end{array}$ & $\begin{array}{l}\text { Duan et al. } \\
\text { (2015a) }\end{array}$ \\
\hline Zeolite & PA & $97,212-286 \mathrm{~nm}$ & $\begin{array}{l}0.2 \%(\mathrm{w} / \mathrm{v}) \text { in organic } \\
\text { phase }\end{array}$ & $\mathrm{IP}$ & $\mathrm{RO}$ & $\begin{array}{l}\text { Smaller NPs produced } \\
\text { higher permeability } \\
\text { enhancements, but larger } \\
\text { NPs produced more } \\
\text { surface properties change }\end{array}$ & Li et al. (2013) \\
\hline Silica & PA & $3-16 \mathrm{~nm}$ & $\begin{array}{l}0-0.4 \%(3 \mathrm{~nm}) \text { and } \\
0-0.5 \%(16 \mathrm{~nm}) \text { in } \\
\text { aqueous phase }\end{array}$ & $\mathrm{IP}$ & $\mathrm{RO}$ & $\begin{array}{l}\mathrm{Pw} \uparrow ; \mathrm{NaCl} \text { rejection } \nearrow \searrow \text {; } \\
\text { Thermal stability } \uparrow\end{array}$ & $\begin{array}{l}\text { Jadav and } \\
\text { Singh, (2009) }\end{array}$ \\
\hline Oxidized MWNT's & PVA & $\begin{array}{l}\text { OD:8-15 nm; L: } \\
\text { 10-50 } \mu \mathrm{m}\end{array}$ & $10 \%$ of PVA & $\begin{array}{l}\text { Coating + Cross- } \\
\text { linking }\end{array}$ & $\begin{array}{l}\text { UF of oil/water } \\
\text { emulsion }\end{array}$ & 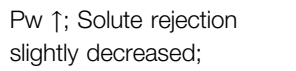 & $\begin{array}{l}\text { Ma et al. } \\
(2010)\end{array}$ \\
\hline Cellulose Nanofibers & & $\begin{array}{l}\text { OD: } 5 \mathrm{~nm} ; \mathrm{L} \\
<10 \mu \mathrm{m}\end{array}$ & $\begin{array}{l}0.25 \text { and } 1.25 \% \\
\text { of PVA }\end{array}$ & & & $\begin{array}{l}\text { Suggested the presence of } \\
\text { directional water channels } \\
\text { through the interface } \\
\text { between filler and PVA } \\
\text { matrix }\end{array}$ & \\
\hline Carboxylic MWNTs & Polyester & $\begin{array}{l}\mathrm{OD}<8 \mathrm{~nm} ; \mathrm{L}= \\
10-30 \mu \mathrm{m}\end{array}$ & $\begin{array}{l}0.05 \%(w / v) \text { in } \\
\text { aqueous phase }\end{array}$ & $\begin{array}{l}\text { Modified IP; O/ } \\
\text { A/O }\end{array}$ & NF & $\begin{array}{l}\mathrm{PW} \uparrow ; \mathrm{Na}_{2} \mathrm{SO}_{4} \text { rejection } \uparrow \text {; } \\
\text { Immerse support layer into } \\
\text { organic phase before } \\
\text { conventional IP process } \\
\text { improved TFN } \\
\text { performance }\end{array}$ & $\begin{array}{l}\text { Wu et al. } \\
(2010)\end{array}$ \\
\hline MWNTs & PA & $\begin{array}{l}\mathrm{OD}=9-12 \mathrm{~nm} \\
\mathrm{~L}=10-15 \mu \mathrm{m}\end{array}$ & $\begin{array}{l}0.1,0.5,1,5 \%(\mathrm{w} / \mathrm{v}) \\
\text { in aqueous phase }\end{array}$ & $\mathrm{IP}$ & $\mathrm{RO}$ & $\begin{array}{l}\text { Surfactant (Triton X-100) } \\
\text { was used to facilitate the } \\
\text { dispersion of MWNTs; } \\
\text { Chlorine resistance } \uparrow\end{array}$ & $\begin{array}{l}\text { Park J. et al. } \\
(2010)\end{array}$ \\
\hline Zeolite (LTA) & PA & $\sim 250 \mathrm{~nm}$ & $\begin{array}{l}0.2 \% \text { in organic } \\
\text { phase }\end{array}$ & $\mathrm{IP}$ & Seawater RO & $\begin{array}{l}\text { Under } 800 \text { psi, optimal } \\
\text { permeate flux is around } \\
42 \mathrm{~L} / \mathrm{m} 2 \mathrm{~h}, \mathrm{NaCl} \text { rejection } \\
(99.4 \%, 32,000 \mathrm{mg} / \mathrm{L}) ; \\
\text { Defects and molecular- } \\
\text { sieving largely govern } \\
\text { transport through zeolite- } \\
\text { TFN membrane }\end{array}$ & $\begin{array}{l}\text { Lind et al. } \\
\text { (2010) }\end{array}$ \\
\hline Functionalized Silica & PA & - & $\begin{array}{l}0.04,0.4 \% \text { in } \\
\text { aqueous phase }\end{array}$ & $\mathrm{IP}$ & $\mathrm{RO} ; \mathrm{PV}$ & $\begin{array}{l}\text { Small-angle neutron } \\
\text { scattering (SANS) was } \\
\text { used to study the } \\
\text { dispersion of silica NPs in } \\
\text { thin-film layer; Thermal } \\
\text { (Continued on fo }\end{array}$ & llowing page) \\
\hline
\end{tabular}


TABLE 4 | (Continued) Summary of TFNs and their composition, performance, fabrication and applications.

\begin{tabular}{|c|c|c|c|c|c|c|c|}
\hline \multicolumn{2}{|l|}{ TFN } & \multirow[t]{2}{*}{ Particle size } & \multirow{2}{*}{$\begin{array}{l}\text { Loading wt } \% \text { (best } \\
\text { performance) }\end{array}$} & \multirow{2}{*}{$\begin{array}{l}\text { Fabrication } \\
\text { method }\end{array}$} & \multirow[t]{2}{*}{ Application } & \multirow[t]{2}{*}{ Performance } & \multirow[t]{2}{*}{ References } \\
\hline Filler & Polymer & & & & & & \\
\hline & & & & & & 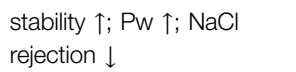 & \\
\hline $\begin{array}{l}\text { Functionalized } \\
\text { MWNTs }\end{array}$ & PA & $\begin{array}{l}\mathrm{OD}=\sim 30 \mathrm{~nm} \\
\mathrm{~L} 1=10-30 \mu \mathrm{m} \\
\mathrm{L} 2= \\
0.5-2.0 \mu \mathrm{m}\end{array}$ & $\begin{array}{l}0.01-0.06 \% \text { in } \\
\text { aqueous or organic } \\
\text { phase }\end{array}$ & $\mathbb{I P}$ & NF & $\begin{array}{l}\text { Pw } \uparrow \text {; Solute rejection no } \\
\text { change; Nanogaps around } \\
\text { the external surface of } \\
\text { fillers provide a low } \\
\text { resistance solvent pathway }\end{array}$ & $\begin{array}{l}\text { Roy et al. } \\
\text { (2011) }\end{array}$ \\
\hline Oxidized; MWNTs & PA & - & $\begin{array}{l}0-0.2 \%(w / v) \text { in } \\
\text { aqueous phase }\end{array}$ & $\mathrm{IP}$ & $\mathrm{RO}$ & $\begin{array}{l}\text { Surface hydrophilicity } \uparrow \text {; } \\
\mathrm{Pw} \uparrow ; \mathrm{NaCl} \text { rejection } \downarrow\end{array}$ & $\begin{array}{l}\text { Zhang et al. } \\
\text { (2011) }\end{array}$ \\
\hline $\begin{array}{l}\text { Metal alkoxide (TTIP, } \\
\text { BTESE, PhTES) }\end{array}$ & PA & - & $\begin{array}{l}0-5 \% \text { in organic } \\
\text { phase }\end{array}$ & $\mathrm{IP}$ & $\mathrm{NF} / \mathrm{RO}$ & $\begin{array}{l}\text { Pore size } \uparrow \text {; Pw } \uparrow \text {; With } \\
\text { PhTES, Pw } \uparrow, \mathrm{NaCl} \\
\text { rejection no change }\end{array}$ & $\begin{array}{l}\text { Kong et al. } \\
\text { (2011) }\end{array}$ \\
\hline Zeolite (NaX) & PA & $40-150 \mathrm{~nm}$ & $\begin{array}{l}0.004,0.01,0.04 \\
0.2 \%(\mathrm{w} / \mathrm{v}) \text { in organic } \\
\text { phase }(0.2 \%)\end{array}$ & $\mathbb{I P}$ & $\mathrm{RO}$ & $\begin{array}{l}\text { Thermal stability } \uparrow \text {; } \\
\text { Hydrophilicity } \uparrow \text {; Pw } \uparrow \text {; } \\
\mathrm{NaCl} \text { rejection no change }\end{array}$ & $\begin{array}{l}\text { Fathizadeh } \\
\text { et al. (2011) }\end{array}$ \\
\hline $\begin{array}{l}\text { Hydrophilized } \\
\text { ordered } \\
\text { mesoporous } \\
\text { carbon (OMC) }\end{array}$ & PA & - & $\begin{array}{l}0-10 \% \text { in aqueous } \\
\text { phase }(5 \%)\end{array}$ & $\mathrm{IP}$ & NF & $\begin{array}{l}\text { Hydrophilicity } \uparrow \text {; Protein } \\
\text { adsorption } \downarrow \text {; } \mathrm{PW} \uparrow \text {; } \mathrm{NaCl} \\
\text { rejection } \downarrow ; \mathrm{Na} 2 \mathrm{SO} 4 \\
\text { rejection slightly } \downarrow\end{array}$ & $\begin{array}{l}\text { Kim and } \\
\text { Deng, (2011) }\end{array}$ \\
\hline $\begin{array}{l}\text { Hydrophilic } \\
\text { macromolecules } \\
+\mathrm{Ag}+\end{array}$ & PA & $11,000 \mathrm{Da}$ & $\begin{array}{l}0.25 \% \text { of }(\mathrm{MDI}+ \\
\mathrm{PEG} \text { ) in organic } \\
\text { phase; } 0.25 \% \text { of } \\
\mathrm{AgNO}_{3} \text { in aqueous } \\
\text { phase }\end{array}$ & $\mathrm{IP}$ & Seawater RO & $\begin{array}{l}\text { Good seawater } \\
\text { desalination performance; } \\
\text { Fouling resistance } \uparrow \text {; } \\
\text { Biofouling resistance } \uparrow\end{array}$ & $\begin{array}{l}\text { Rana D. et al. } \\
\text { (2011) }\end{array}$ \\
\hline Ag NPs & PA & $\begin{array}{l}\text { Several } \\
\text { nanometers }\end{array}$ & $\begin{array}{l}\text { Dispersed in } \\
\text { aqueous phase } \\
\text { Finally, } 10 \% \text { in PA }\end{array}$ & $\mathrm{IP}$ & NF & $\begin{array}{l}\text { Surface hydrophilicity } \uparrow \text {; } \\
\text { Pw } \uparrow ; \text { Salt rejection no } \\
\text { change; Biofouling } \\
\text { resistance } \uparrow\end{array}$ & $\begin{array}{l}\text { Kim et al. } \\
(2012)\end{array}$ \\
\hline $\begin{array}{l}\text { Mesoporous silica } \\
\text { (MCM-41) and } \\
\text { nonporous silica }\end{array}$ & PA & $\begin{array}{l}\sim 100 \mathrm{~nm} ; ~ \sim \\
100 \mathrm{~nm}\end{array}$ & $\begin{array}{l}0-0.1 \% \text { in organic } \\
\text { phase }(0.05 \%)\end{array}$ & $\mathrm{IP}$ & $\mathrm{RO}$ & $\begin{array}{l}\text { Surface hydrophilicity } \uparrow \text {; } \\
\text { Pw } \uparrow \text {; Salt rejection no } \\
\text { change; Under } 300 \text { psi, } \\
\text { optimal permeate flux is } \\
46.6 \mathrm{~L} / \mathrm{m} 2 \mathrm{~h}, \mathrm{NaCl} \text { rejection } \\
(97.9,2000 \mathrm{mg} / \mathrm{L}) \text {; Porous } \\
\text { structures of filler } \\
\text { contributed significantly to } \\
\text { the water flux } \\
\text { enhancement }\end{array}$ & $\begin{array}{l}\text { Yin et al. } \\
(2012)\end{array}$ \\
\hline $\begin{array}{l}\text { Proteoliposome with } \\
\text { aquaporin }\end{array}$ & PA & $<150 \mathrm{~nm}$ & $\begin{array}{l}10 \mathrm{mg} / \mathrm{ml} \text { in aqueous } \\
\text { phase }\end{array}$ & $\mathrm{IP}$ & $\mathrm{RO}$ & $\begin{array}{l}\mathrm{Pw} \uparrow \text {; Salt rejection no } \\
\text { change; Under } 72.5 \mathrm{psi} \text {, } \\
\text { water flux is } 20 \mathrm{~L} / \mathrm{m} 2 \mathrm{~h} \text {, } \\
\mathrm{NaCl} \text { rejection }(\sim 97 \% \text {, } \\
584.4 \mathrm{mg} / \mathrm{L})\end{array}$ & $\begin{array}{l}\text { Zhao et al. } \\
\text { (2012) }\end{array}$ \\
\hline $\begin{array}{l}\text { Aluminosilicate } \\
\text { SWNTs }\end{array}$ & PVA & $\begin{array}{l}\mathrm{OD}=2.7 \mathrm{~nm} ; \mathrm{L} \\
>200 \mathrm{~nm}\end{array}$ & $\begin{array}{l}0-20 \%(v / v) \text { in PVA } \\
\text { solution }\end{array}$ & $\begin{array}{l}\text { Coating + Cross- } \\
\text { linking }\end{array}$ & NF & $\begin{array}{l}\text { Surface hydrophilicity } \uparrow \text {; } \\
\text { Roughness } \downarrow \text {; PW } \uparrow \text {; Salt } \\
\text { rejection } \uparrow\end{array}$ & $\begin{array}{l}\text { Baroña et al. } \\
\text { (2012) }\end{array}$ \\
\hline Zeolite (NaY) & PA & $40-150 \mathrm{~nm}$ & $\begin{array}{l}0-0.4 \%(\mathrm{w} / \mathrm{v}) \text { in } \\
\text { organic phase }(0.1 \%)\end{array}$ & $\mathrm{IP}$ & $\mathrm{FO}$ & $\begin{array}{l}\mathrm{PW} \nearrow \searrow ; \mathrm{NaCl} \text { rejection } \\
\searrow \nearrow ; \text { Surface } \\
\text { roughness } \nearrow \searrow\end{array}$ & $\begin{array}{l}\text { Ma et al. } \\
(2012)\end{array}$ \\
\hline Alumina NPs & PA & $\sim 14 \mathrm{~nm}$ & $1 \%$ in organic phase & $\mathrm{IP}$ & NF & $\begin{array}{l}\text { Surface hydrophilicity } \uparrow \text {; } \\
\text { Pw } \uparrow \text {; Salt rejection no } \\
\text { change }\end{array}$ & $\begin{array}{l}\text { Saleh and } \\
\text { Gupta, (2012) }\end{array}$ \\
\hline Oxidized MWNTs & PA & $\begin{array}{l}\mathrm{OD}=5-10 \mathrm{~nm} \\
\mathrm{~L}=10-30 \mu \mathrm{m}\end{array}$ & $5 \%$ of $\mathrm{PA}$ & $\mathrm{IP}$ & $\begin{array}{l}\text { Oil sand } \\
\text { process- } \\
\text { affected water } \\
\text { treatment }\end{array}$ & $\begin{array}{l}\text { Water flux } \uparrow \text {; Organic } \\
\text { fraction rejection } \uparrow \text {; Fouling } \\
\text { resistance } \uparrow\end{array}$ & $\begin{array}{l}\text { Kim S. G. } \\
\text { et al. (2013) }\end{array}$ \\
\hline $\begin{array}{l}\text { Zwitterion } \\
\text { functionalized CNTs }\end{array}$ & PA & $\begin{array}{l}\mathrm{OD}=1.5 \mathrm{~nm} ; \mathrm{L} \\
=1 \mu \mathrm{m}\end{array}$ & $\begin{array}{l}0,9,20 \% \text { of } \\
\text { PA }(20 \%)\end{array}$ & Deposition + IP & $\mathrm{RO}$ & $\begin{array}{l}\text { Water flux and salt } \\
\text { rejection } \uparrow \text {; Under } 530 \text { psi, } \\
\text { optimal water flux is } \\
48.8 \mathrm{~L} / \mathrm{m} 2 \mathrm{~h}, \mathrm{NaCl} \text { rejection } \\
(98.6 \%, 2,542 \mathrm{mg} / \mathrm{L})\end{array}$ & $\begin{array}{l}\text { Chan et al. } \\
\text { (2013) }\end{array}$ \\
\hline Carboxylic MWNTs & PA & & & Deposition + IP & $\mathrm{RO}$ & & \\
\hline
\end{tabular}


TABLE 4 | (Continued) Summary of TFNs and their composition, performance, fabrication and applications.

\begin{tabular}{|c|c|c|c|c|c|c|c|}
\hline \multicolumn{2}{|l|}{ TFN } & \multirow[t]{2}{*}{ Particle size } & \multirow{2}{*}{$\begin{array}{l}\text { Loading wt\%(best } \\
\text { performance) }\end{array}$} & \multirow{2}{*}{$\begin{array}{l}\text { Fabrication } \\
\text { method }\end{array}$} & \multirow[t]{2}{*}{ Application } & \multirow[t]{2}{*}{ Performance } & \multirow[t]{2}{*}{ References } \\
\hline Filler & Polymer & & & & & & \\
\hline & & $\begin{array}{l}\mathrm{OD}<8 \mathrm{~nm} ; \mathrm{L}= \\
10-30 \mu \mathrm{m}\end{array}$ & $\begin{array}{l}3 \text { mg per membrane } \\
\text { sample }\end{array}$ & & & $\begin{array}{l}\text { High electrical conductivity } \\
(\sim 400 \mathrm{~S} / \mathrm{m}), \mathrm{NaCl} \text { rejection } \\
\text { (>95\%, } 1000 \mathrm{mg} / \mathrm{L}) \text {, high } \\
\text { water flux; Biofouling } \\
\text { resistance } \uparrow \text { under electric } \\
\text { potential }\end{array}$ & $\begin{array}{l}\text { de Lannoy } \\
\text { et al. (2013) }\end{array}$ \\
\hline Oxidized MWNTs & PVA & $\begin{array}{l}\mathrm{OD}= \\
10-30 \mathrm{~nm} ; \mathrm{L}= \\
0.5-2 \mu \mathrm{m}\end{array}$ & $0,5,10,15 \%$ of PVA & $\begin{array}{l}\text { Electrospinning + } \\
\text { Cross-linking }\end{array}$ & UF & $\begin{array}{l}\text { Water flux } \uparrow \text {; Organic } \\
\text { fraction rejection (99.5\%); } \\
\text { Good mechanical } \\
\text { properties }\end{array}$ & $\begin{array}{l}\text { You et al. } \\
(2013)\end{array}$ \\
\hline $\begin{array}{l}\text { PMMA modified } \\
\text { MWNTs }\end{array}$ & PA & $\begin{array}{l}\mathrm{OD}= \\
20-30 \mathrm{~nm} ; \mathrm{L}< \\
50 \mu \mathrm{m}\end{array}$ & $\begin{array}{l}0-5.4 \mathrm{~g} / \mathrm{L} \text { in organic } \\
\text { phase }(0.67 \mathrm{~g} / \mathrm{L})\end{array}$ & $\mathrm{IP}$ & NF & Pw and selectivity $\uparrow$ & $\begin{array}{l}\text { Shen et al. } \\
\text { (2013) }\end{array}$ \\
\hline $\begin{array}{l}\text { PMMA modified } \\
\text { MWNTs }\end{array}$ & $\mathrm{PA}$ & $\begin{array}{l}\mathrm{OD}= \\
20-30 \mathrm{~nm} ; \mathrm{L}< \\
10 \mu \mathrm{m}\end{array}$ & $\begin{array}{l}0.67,1.33,2.0 \mathrm{~g} / \mathrm{L} \text { in } \\
\text { organic phase }(0.67)\end{array}$ & $\mathbb{I P}$ & NF & $\begin{array}{l}\text { Under } 145 \text { psi, optimal } \\
\text { water flux is } 69.7 \mathrm{~L} / \mathrm{m} 2 \mathrm{~h} \text {, } \\
\mathrm{Na}_{2} \mathrm{SO}_{4} \text { rejection }(99.0 \% \text {, } \\
2000 \mathrm{mg} / \mathrm{L})\end{array}$ & $\begin{array}{l}\text { Yu et al. } \\
(2013)\end{array}$ \\
\hline Carboxylic MWNTs & $\mathrm{PA}$ & $\begin{array}{l}\mathrm{OD}<8 \mathrm{~nm} ; \mathrm{L}= \\
10-30 \mu \mathrm{m}\end{array}$ & $\begin{array}{l}0-2.0 \mathrm{mg} / \mathrm{ml} \text { in } \\
\text { aqueous phase }(0.5)\end{array}$ & $\begin{array}{l}\text { Modified IP; O/ } \\
\text { A/O }\end{array}$ & NF & $\begin{array}{l}\mathrm{PW} \nearrow \searrow \text {; Hydrophilicity } \\
\nearrow \searrow \text {; Under } 87 \mathrm{psi}, \\
\text { optimal water flux is } \\
21.2 \mathrm{~L} / \mathrm{m}^{2} \mathrm{~h}, \mathrm{Na}_{2} \mathrm{SO}_{4} \\
\text { rejection }(>70 \% \\
5 \mathrm{mmol} / \mathrm{L})\end{array}$ & $\begin{array}{l}\text { Wu et al. } \\
\text { (2013a) }\end{array}$ \\
\hline $\begin{array}{l}\text { Amine functionalized } \\
\text { MWNTs }\end{array}$ & PA & $\begin{array}{l}\mathrm{OD}=\sim 5 \mathrm{~nm} ; \mathrm{L} \\
=\sim 50 \mu \mathrm{m}\end{array}$ & $\begin{array}{l}0.01,0.05,0.1 \% \text { in } \\
\text { aqueous phase }\end{array}$ & $\mathrm{IP}$ & $\mathrm{FO}$ & $\begin{array}{l}\text { Hydrophilicity } \uparrow ; \text { S value } \downarrow \text {; } \\
\text { Pw and salt rejection } \uparrow \text { in } \\
\text { both AL-FS and AL-DS } \\
\text { modes }\end{array}$ & $\begin{array}{l}\text { Amini et al. } \\
\text { (2013) }\end{array}$ \\
\hline Zeolite (Silicalite-1) & PA & - & $\begin{array}{l}0-0.2 \% \text { in organic } \\
\text { phase }\end{array}$ & $\mathrm{IP}$ & $\mathrm{RO}$ & $\begin{array}{l}\text { Pw, hydrophilicity, and } \\
\text { acid stability } \uparrow \text {; Silicalite- } 1 \\
\text { is superior to } \mathrm{NaA} \text { in } \\
\text { fabricating TFN }\end{array}$ & $\begin{array}{l}\text { Huang et al. } \\
\text { (2013a) }\end{array}$ \\
\hline Zeolite (NaA) & PA & - & $\begin{array}{l}0-0.2 \%(w / v) \text { in } \\
\text { organic phase }\end{array}$ & $\mathrm{IP}$ & $\mathrm{RO}$ & $\begin{array}{l}\text { Water flux and salt } \\
\text { rejection } \uparrow\end{array}$ & $\begin{array}{l}\text { Huang et al. } \\
(2013 b)\end{array}$ \\
\hline Aminated Zeolite & PA & $\leq 100 \mathrm{~nm}$ & $\begin{array}{l}0.02 \% \text { in aqueous } \\
\text { solution }\end{array}$ & $\mathrm{IP}$ & $\mathrm{RO}$ & $\begin{array}{l}\mathrm{Pw} \uparrow \text {; Chlorine resistance } \\
\uparrow \text {; Under } 800 \mathrm{psi} \text {, water } \\
\text { flux is } 37.8 \mathrm{~L} / \mathrm{m} 2 \mathrm{~h}, \mathrm{NaCl} \\
\text { rejection is } 98.8 \% \\
(32,000 \mathrm{mg} / \mathrm{L})\end{array}$ & $\begin{array}{l}\text { Kim S. G. } \\
\text { et al. (2013) }\end{array}$ \\
\hline Zeolite A & PA & $250 \mathrm{~nm}$ & $\begin{array}{l}0.2 \% \text { in organic } \\
\text { phase }\end{array}$ & $\mathrm{IP}$ & $\mathrm{RO}$ & $\begin{array}{l}\text { Pw and salt rejection } \uparrow \text {; } \\
\text { Resistance to physical } \\
\text { compaction } \uparrow\end{array}$ & $\begin{array}{l}\text { Pendergast } \\
\text { et al. (2013) }\end{array}$ \\
\hline $\begin{array}{l}\text { Modified } \\
\text { mesoporous silica }\end{array}$ & PA & $\sim 100 \mathrm{~nm}$ & $\begin{array}{l}0-0.07 \% \text { in aqueous } \\
\text { phase }(0.03 \%)\end{array}$ & IP & NF & $\begin{array}{l}\text { Under } 87 \text { psi, optimal } \\
\text { water flux is } 32.4 \mathrm{~L} / \mathrm{m} 2 \mathrm{~h} \text {, } \\
\mathrm{Na}_{2} \mathrm{SO}_{4} \text { rejection (> } 80 \% \text {, } \\
5 \mathrm{mmol} / \mathrm{L})\end{array}$ & $\begin{array}{l}\text { Wu et al. } \\
(2013 b)\end{array}$ \\
\hline Mesoporous silica & PA & $\sim 164 \mathrm{~nm}$ & $\begin{array}{l}0-0.1 \%(w / v) \text { in } \\
\text { organic phase }(0.1)\end{array}$ & $\mathrm{IP}$ & $\mathrm{RO}$ & $\begin{array}{l}\text { Pw and hydrophilicity } \uparrow \text {; } \\
\text { Under } 232 \text { psi, optimal } \\
\text { water flux is } 53 \mathrm{~L} / \mathrm{m} 2 \mathrm{~h} \text {, } \\
\mathrm{NaCl} \text { rejection (>96\%, } \\
2,000 \mathrm{mg} / \mathrm{L})\end{array}$ & $\begin{array}{l}\text { Bao et al. } \\
(2013)\end{array}$ \\
\hline $\begin{array}{l}\text { Aminated hyper } \\
\text { branched silica }\end{array}$ & PA & $\sim 7 \mathrm{~nm}$ & $\begin{array}{l}0.02 \% \text { in aqueous } \\
\text { solution }\end{array}$ & $\mathbb{P}$ & $\mathrm{RO}$ & $\begin{array}{l}\mathrm{Pw} \uparrow \text {; Chlorine resistance } \\
\uparrow \text {; Under } 800 \mathrm{psi} \text {, water } \\
\text { flux is } 34.5 \mathrm{~L} / \mathrm{m} 2 \mathrm{~h}, \mathrm{NaCl} \\
\text { rejection is } 97.7 \% \\
(32,000 \mathrm{mg} / \mathrm{L})\end{array}$ & $\begin{array}{l}\text { Kim K. S. } \\
\text { et al. (2013) }\end{array}$ \\
\hline Silica & Fluoropolyamide & - & $\begin{array}{l}0-1.0 \%(\mathrm{w} / \mathrm{v}) \text { in } \\
\text { aqueous phase }(0.1)\end{array}$ & $\mathrm{IP}$ & NF & $\begin{array}{l}\mathrm{Pw} \uparrow ; \mathrm{Na}_{2} \mathrm{SO}_{4} \text { rejection } \\
\nearrow \searrow ; \text { Under } 87 \text { psi, } \\
\text { optimal water flux is } \\
15.2 \mathrm{~L} / \mathrm{m}^{2} \mathrm{~h}, \mathrm{Na}_{2} \mathrm{SO}_{4} \\
\text { rejection (85.0\%, } \\
2000 \mathrm{mg} / \mathrm{L})\end{array}$ & $\begin{array}{l}\text { Hu et al. } \\
(2013)\end{array}$ \\
\hline
\end{tabular}


TABLE 4 | (Continued) Summary of TFNs and their composition, performance, fabrication and applications.

\begin{tabular}{|c|c|c|c|c|c|c|c|}
\hline \multicolumn{2}{|l|}{ TFN } & \multirow[t]{2}{*}{ Particle size } & \multirow{2}{*}{$\begin{array}{l}\text { Loading wt\%(best } \\
\text { performance) }\end{array}$} & \multirow{2}{*}{$\begin{array}{l}\text { Fabrication } \\
\text { method }\end{array}$} & \multirow[t]{2}{*}{ Application } & \multirow[t]{2}{*}{ Performance } & \multirow[t]{2}{*}{ References } \\
\hline Filler & Polymer & & & & & & \\
\hline $\begin{array}{l}\text { Aluminosilicate } \\
\text { SWNT }\end{array}$ & & $\begin{array}{l}\mathrm{OD}=\sim 2.7 \mathrm{~nm} \\
\mathrm{~L}=150 \mathrm{~nm}\end{array}$ & $\begin{array}{l}0.05,0.1,0.2 \%(\mathrm{w} / \mathrm{v}) \\
\text { in organic phase }\end{array}$ & $\begin{array}{l}\text { IP (single } \\
\text { pass flow) }\end{array}$ & $\begin{array}{l}\text { Low } \\
\text { pressure RO }\end{array}$ & $\begin{array}{l}\text { Pw and salt rejection } \uparrow \text {; } \\
\text { Resistance to physical } \\
\text { compaction } \uparrow\end{array}$ & $\begin{array}{l}\text { Baroña et al. } \\
\text { (2013) }\end{array}$ \\
\hline Aminosilanized $\mathrm{TiO}_{2}$ & PA & $\sim 21 \mathrm{~nm}$ & $\begin{array}{l}0.005,0.05,0.1 \% \text { in } \\
\text { aqueous solution } \\
(0.005 \%)\end{array}$ & $\mathbb{I P}$ & NF & $\begin{array}{l}\text { Pw and selectivity } \uparrow \text {; } \\
\text { Thermal stability } \uparrow \text {; Under } \\
110 \text { psi, optimal water flux } \\
\text { is } 12.3 \mathrm{~L} / \mathrm{m} 2 \mathrm{~h}, \mathrm{NaCl} \\
\text { rejection is } 54 \% \\
(2,000 \mathrm{mg} / \mathrm{L})\end{array}$ & $\begin{array}{l}\text { Rajaeian et al. } \\
\text { (2013) }\end{array}$ \\
\hline $\begin{array}{l}\text { Organoclay (Cloisite } \\
15 \mathrm{~A} \text { and } 30 \mathrm{~B})\end{array}$ & Chitosan & - & $\begin{array}{l}0.5,1,2 \% \text { in casting } \\
\text { solution }\end{array}$ & $\begin{array}{l}\text { Coating on PVDF } \\
\text { substrate }\end{array}$ & $\begin{array}{l}\text { NF for dye } \\
\text { removal }\end{array}$ & $\begin{array}{l}\text { Dye removal } \uparrow \text {; Adsoption } \\
\text { is the dominating removal } \\
\text { mechanism }\end{array}$ & $\begin{array}{l}\text { Daraei et al. } \\
(2013)\end{array}$ \\
\hline $\begin{array}{l}\text { Proteoliposome } \\
\text { containing } \\
\text { Aquaporin Z }\end{array}$ & PEl & 107.8 nm & $\begin{array}{l}0,50,200,400 \text { in } \\
\text { Lipid-to-protein } \\
\text { ratio (200) }\end{array}$ & PEl crosslinking & NF & $\begin{array}{l}\text { Under } 14.5 \text { psi, optimal } \\
\text { water flux is } 36.6 \mathrm{~L} / \mathrm{m} 2 \mathrm{~h} \\
\mathrm{MgCl}_{2} \text { rejection }(95 \% \text {, } \\
100 \mathrm{mg} / \mathrm{L})\end{array}$ & Li et al. (2014) \\
\hline Carboxylic MWNTs & PA & $\begin{array}{l}\mathrm{OD}= \\
20-40 \mathrm{~nm} ; \mathrm{L}= \\
1-5 \mu \mathrm{m}\end{array}$ & $\begin{array}{l}0-0.1 \% \text { in MPD } \\
\text { solution }\end{array}$ & $\mathrm{IP}$ & $\mathrm{RO}$ & $\begin{array}{l}\text { Hydrophilicity } \uparrow \text {; Water flux } \\
\uparrow \text {; Solute rejection no } \\
\text { change; Better antifouling } \\
\text { and antioxidative } \\
\text { properties }\end{array}$ & $\begin{array}{l}\text { Zhao et al. } \\
\text { (2014) }\end{array}$ \\
\hline
\end{tabular}

IP, interfacial polymerization; PA:polyamide; PV, pervaporation; PW, water permeability.

the aromatic polyamide membranes resulting in an increase in the chlorine resistance of the membrane. TFNs having carboxylfunctionalized MWCNTs as fillers have also been known to show high chlorine resistance (Park J. et al., 2010). Interactions between the carboxyl group and amide layer is understood to be the reason causing this behavior. Table 4 attempts to summarize a majority of the TFNs reported in literature (Petersen, 1993; Mills and Le Hunte, 1997; Kim et al., 2000; Williams, 2003; Kim et al., 2004; Chou et al., 2005; Wang et al., 2005; Louie et al., 2006; Jeong et al., 2007; Lee et al., 2007; Ghosh et al., 2008; Lee et al., 2008; Liu et al., 2008; Park et al., 2008; Rahimpour et al., 2008; Singh and Aswal, 2008; Ghosh and Hoek, 2009; Jadav and Singh, 2009; Lind et al., 2009b; Zhou et al., 2009; Zodrow et al., 2009; Jadav et al., 2010; Li and Wang, 2010; Lind et al., 2010; Ma et al., 2010; Park K. T. et al., 2010; Park J. et al., 2010; Paz, 2010; Wu et al., 2010; Zhu et al., 2010; Rana D. et al., 2011; Rana T. M. D. et al., 2011; Roy et al., 2011; Kim and Deng, 2011; Kong et al., 2011; Pendergast and Hoek, 2011; Zhang et al., 2011; Baroña et al., 2012; Daraei et al., 2012; Kim et al., 2012; Lau et al., 2012; Ma et al., 2012; Saleh and Gupta, 2012; Yin et al., 2012; Zhao et al., 2012; Alam et al., 2013; Amini et al., 2013; Bao et al., 2013; Baroña et al., 2013; Chan et al., 2013; Daraei et al., 2013; de Lannoy et al., 2013; Hu et al., 2013; Huang et al., 2013a; Huang et al., 2013b; Jamshidi Gohari et al., 2013; Kim S. G. et al., 2013; Kim E. S. et al., 2013; Kim S. G. et al., 2013; Li and Wang, 2013; Lu et al., 2013; Li et al., 2014; Pendergast et al., 2013; Rajaeian et al., 2013; Shen et al., 2013; Wu et al., 2013b; You et al., 2013; Yu et al., 2013; Wu et al., 2013a; Hermans et al., 2014; Subramani et al., 2014; Zhao et al., 2014; Al-Hobaib et al., 2015; Duan et al., 2015a; Duan et al., 2015b; Ghanbari et al., 2015; Hermans et al., 2015; Lau et al., 2015; Safarpour et al., 2015; Shenvi et al., 2015; NanoH2O and Inc. InterNano, 2021). The arrows under the application column denote the performance of the TFN membrane as compared to the parent TFC membrane. For example, in the first row, the fouling resistance of the membrane with Oxidized MWNT nano-fillers increases when compared with the fouling resistance of the TFC membrane without the nano-fillers.

The following section discusses various desalination processes and the use of TFNs along with specific modifications to improve the desalination performance of the same in detail.

\section{DESALINATION}

It is estimated that only $0.8 \%$ of the water on Earth is freshwater, while the seas and oceans constitute almost $96 \%$ of the water on Earth (Greenlee et al., 2009). To address the increasingly troublesome problem of water shortage around the world, it is important to develop desalination technologies to make use of the salty water from oceans and groundwater aquifers.

The feed water for desalination plants ranges from 10,000 ppm TDS to 60,000 ppm TDS (Mickley, 2001). The concentration of the feed water is the basis upon which desalination plants are designed. Desalination process, energy costs, product recovery and waste management are some of the design choices that are made feed water in mind (Greenlee et al., 2009).

Desalination can be broadly classified into two basic methods; thermal processes and membrane processes (Greenlee et al., 2009). Thermal processes include MED and MFD. MED involves heat transfer between feed water and steam over multiple stages with the aim to desalinate water (Kesieme et al., 2013). The process is optimized with the aim to produce the highest amount of fresh water with the least input of energy. MSF is a commonly used technique which involves passing the 
feed water through a series of flash chambers to heat the feed seawater, after which the condensate is collected separately (Van der Bruggen and Vandecasteele, 2002). Even though MSF is easier and more reliable than MED, it is more expensive and energyintensive (Sagle and Freeman, 2004).

Electrodialysis is a type of membrane process, where the water is passed through a series of parallel cationic and anionic membranes, and an electric current is passed through the seawater to cause separation. This method is suitable only for waters having low concentrations, like brackish water (Reahl, 2004). NF is another membrane based process, but cannot be used as a treatment step on its own as it is not able to bring the water down to drinking water standards (Bohdziewicz et al., 1999). Therefore NF is used in association with RO. RO is one of the most popular membrane based processes, achieving salt rejections of greater than 99\% (Bates and Cuozzo, 2000). RO membranes can be used for both seawater and brackish waters (Greenlee et al., 2009).

The other methods of desalination are Capacitive Deionization (CDI) andMVC (Bates and Cuozzo, 2000; Van der Bruggen and Vandecasteele, 2002). CDI is an electrochemical method in which the ions are separated by electrosorption onto a porous charged electrode (Zhao, 2013). While CDI has advantages like easy cleaning, low cost and good mechanical properties, there is not enough data for implementation on a large scale (Zhao, 2013). MVC follows the same steps as MED or MFD, except that the vapor is condensed into water using mechanical methods. The energy produced by this is then in turn used to heat the feed. Although this process has a high efficiency, it has some drawbacks like that it is difficult to control and complex and so it is used only in small-scale plants (Sagle and Freeman, 2004).

The following subsections compared the major desalination techniques based on factors like energy demand and cost.

\subsection{Energy Demands}

Energy demand is one of the most important considerations that need to be taken into account for desalination.RO consumes the least amount of energy among MED, MSF and RO (Wade, 1993; Wade, 2001). For RO membranes, energy is consumed in pumping water across the membranes while in MSF and MED energy is consumed in converting water to steam and for running pumps (Sagle and Freeman, 2004). Energy consumption is also affected by the salinity of the feed water (Ettouney et al., 2002). Higher concentration of salt in feed water leads to larger osmotic pressure. Larger osmotic pressure means a larger transmembrane pressure needs to be applied which in turn means larger pressure needs to be applied by the pumps, leading to an increase in the energy consumption (Sagle and Freeman, 2004). The energy consumption of TFNs are improved compared to TFCs for the separation process requirement (Subramani et al., 2014).

While MED and MSF require thermal and electrical energy, $\mathrm{RO}$ requires only electrical energy. Assuming water production of $290,000 \mathrm{~m}^{3} /$ day, average total energy consumption (ATEC) in MW (Mega Watt) for the three processes is graphically shown in Figure 7A.

\subsection{Cost}

Figure 7B allows us to compare the three desalination technologies: MED, MSF and RO, based on the energy consumption and the water cost.The energy cost calculations are based on a plant capacity of a volume $32,000 \mathrm{~m}^{3} /$ day; and a total dissolved solids (TDS) concentration of $42,000 \mathrm{mg} / \mathrm{L}$. The energy cost used is $\$ 0.053 / \mathrm{kWh}$. The specific heat consumption (abbreviated as SHC in the figure) is expressed in $\mathrm{kW}_{\text {th }} \mathrm{h} / \mathrm{m}^{3}$ and the specific electricity consumption (abbreviated as SEC in the figure) is expressed in $\mathrm{kW}_{\mathrm{e}} \mathrm{h} / \mathrm{m}^{3}$. The water cost (abbreviated as WC in the figure) calculations are based on a plant capacity of volume $31,822 \mathrm{~m}^{3} /$ day and a TDS concentration of $37,000 \mathrm{mg} / \mathrm{L}$. Energy costs are expressed in $\$ 1.5 / \mathrm{m}^{3}$ (Sagle and Freeman, 2004).

It can be seen that RO has the lowest cost per unit volume. RO membranes have a higher initial cost, but the end result is a higher production rate as compared to MED and MSF (Ettouney et al., 2002; Sagle and Freeman, 2004; Kesieme et al., 2013). In fact, it has been concluded by Kesieme that even with the inclusion of carbon tax in Australia, RO continues to be the most cost effective of the discussed desalination processes (Kesieme et al., 2013).

$\mathrm{RO}$ is the predominant technology used for desalination. Figure 8 shows the (global) cumulative desalination capacity trends (Zhao et al., 2020) and forecast up to 2030 (Shahzad et al., 2019).It is a common practice to improve parameters like salt rejection and permeate flux using various kinds of NPs. The following subsection discusses such modifications that have been reported in the recent times in detail.

\subsection{Improvement in Desalination Performance of TFNs}

It is possible to improve the desalination performance of TFNs by incorporating NPs like functionalized silica nanoparticles (SNs) into the membrane. SNs can be synthesized in various sizes and with differing surface functionalities like epoxy, amine and hydroxyl. The chemistry, surface hydrophilicity and morphology of TFNs are affected by the various factors like size, concentration and surface functionality of the used SNs resulting in an increase in the permeate flux without any drastic change in the salt rejection. Similarly, it is possible to incorporate various other kinds of NPs in order to improve the desalination performance of TFNs (Zargar et al., 2017).

A polyamide TFN has also been reported that has been incorporated with multiwalled carbon nanotubes-titania nanotubes hybrids (MWCNT-TN). The use of acid treated MWCNT-TN as a filler in the PA membrane results in improvement in the surface properties of the membrane (surface charge, contact angle and roughness) resulting in an increase in the water permeability with negligible change in the salt rejection (Wan Azelee et al., 2017).

$\mathrm{ZnO}$ nanostructures like nanorods ( $\mathrm{R}-\mathrm{ZnO})$, nanoflowers $(\mathrm{F}-\mathrm{ZnO})$ and nanospheres $(\mathrm{S}-\mathrm{ZnO})$ have been shown to improve the hydrophilicity of the TFN membrane with increase in the $\mathrm{ZnO}$ loading. Amongst three nanostructures, $\mathrm{S}-\mathrm{ZnO}$ has the largest surface area and smaller size. TFNs with $\mathrm{S}-\mathrm{ZnO}$ incorporated in them were seen to possess the highest 

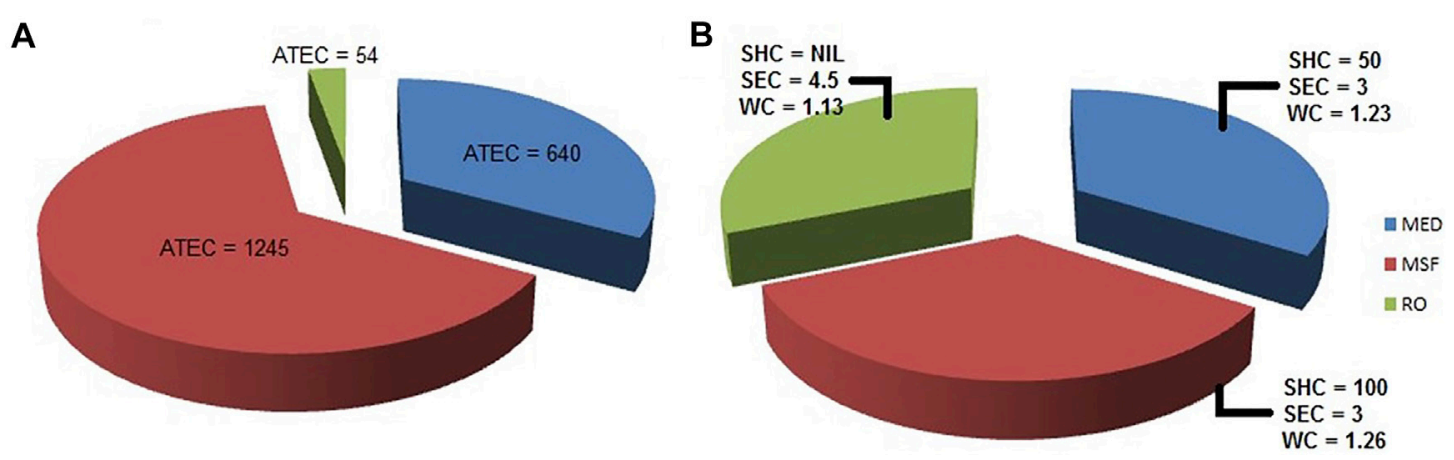

FIGURE 7 | Comparison of MED, MSF and RO. (A) Average total energy consumption (ATEC) expressed in MW (B) Specific heat consumption (SHC) expressed in $\mathrm{kW}$ th $\mathrm{h} / \mathrm{m}^{3}$, specific electricity consumption (SEC) expressed in $\mathrm{kW}$ e $\mathrm{h} / \mathrm{m}^{3}$, and water cost (WC) involved expressed in $\$ 1.5 / \mathrm{m}^{3}$.

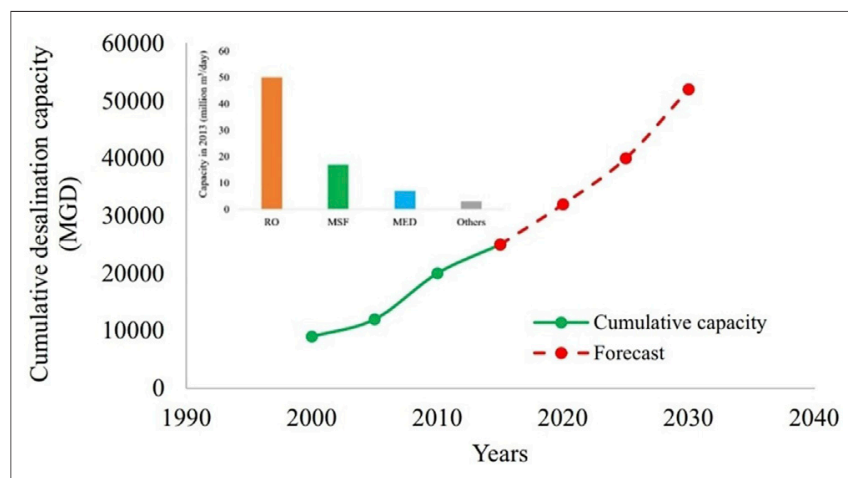

FIGURE 8 | Global cumulative desalination capacity trends and forecast up to 2030 (Zhao et al., 2020). permeate flux with good salt rejection, out of three types of $\mathrm{ZnO}$ nanostructures (Rajakumaran et al., 2020).

Similarly, $\mathrm{Na}+$ functionalized carbon quantum dot $(\mathrm{Na}-$ CQD) incorporated into the PA layer, resulting in a TFN hollow fiber membrane has been shown to possess a much larger effective surface area, a larger number of hydrophilic $\mathrm{O}$-containing groups in the PA layer and a less thickness of the PA layer. These results in a better permeate flux of water enabling use in the desalination of brackish water (Gai et al., 2019).

Another research work done on amino-phenyl modified mesoporous silica NP based TFNs reported a $21.6 \%$ increase in water permeability with a marginal decrease in salt rejection (0.29\%) compared to pure PA membrane under optimum AMSN dosage of $0.25 \mathrm{~g} / \mathrm{L}$ (Wang et al., 2019).

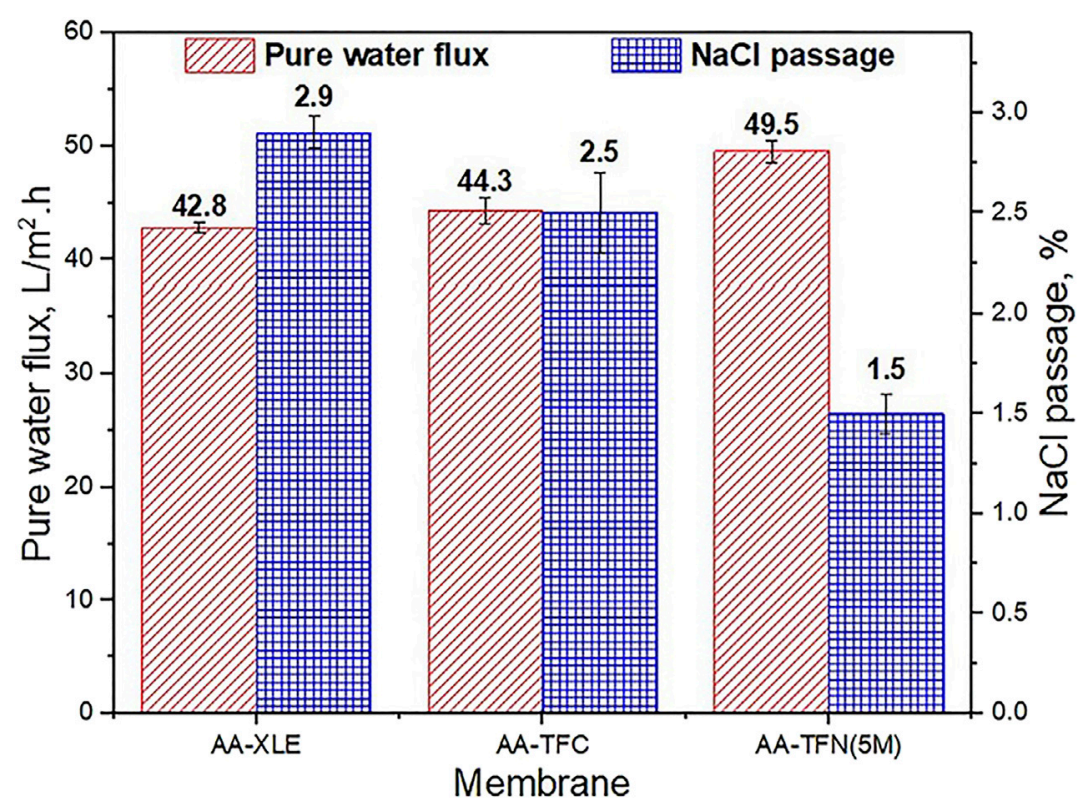

FIGURE 9 | Pure water flux and $\mathrm{NaCl}$ permeability without and with acrylic acid (AA) monomer on the PA surface of TFN membrane (Siew Khoo et al., 2021). 


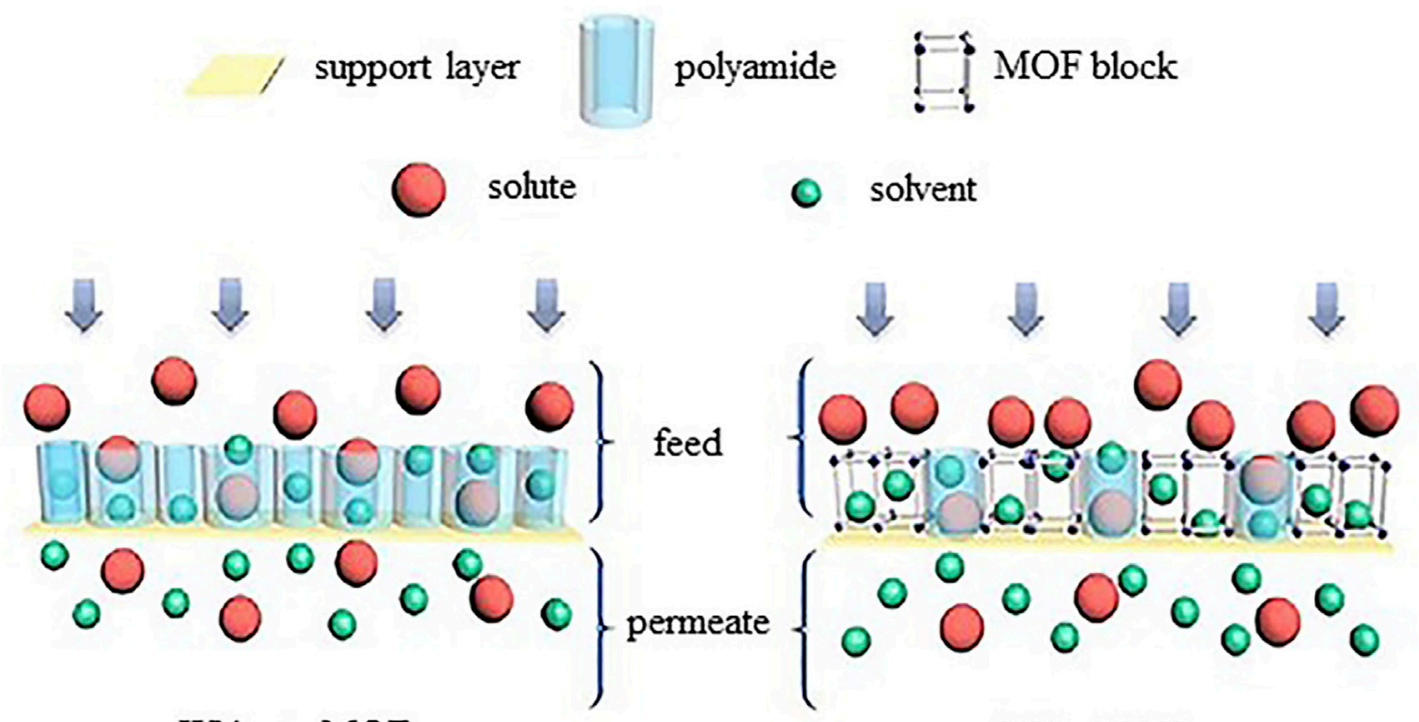

Without MOFs

With MOFs

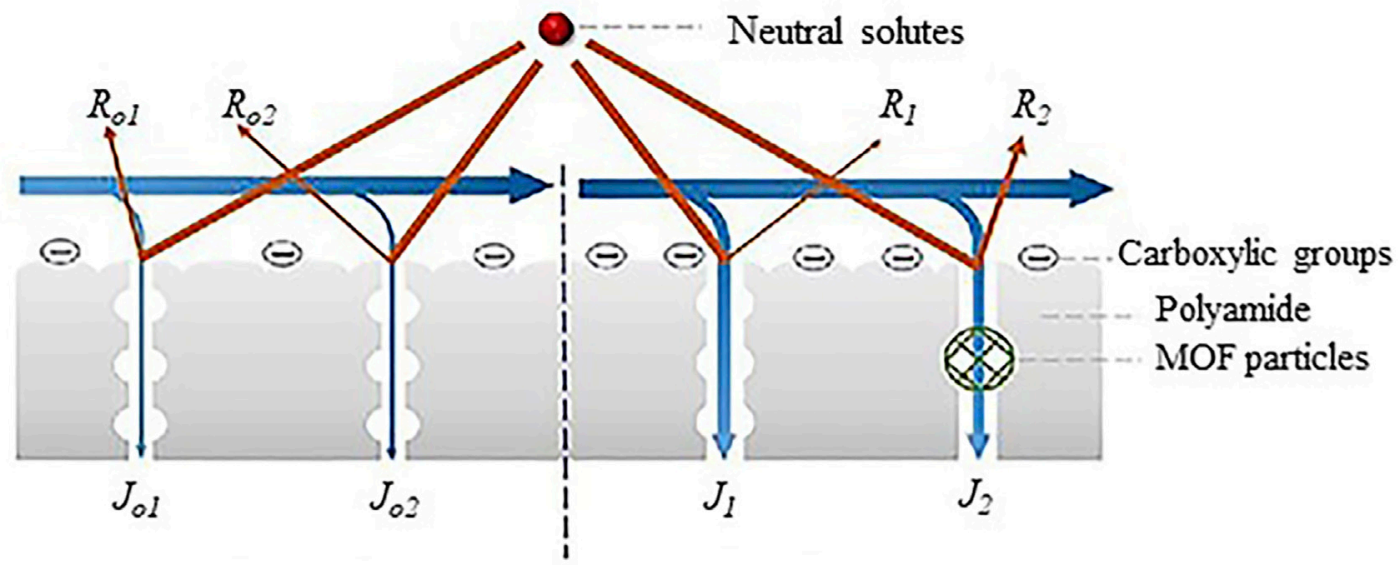

Without MOFs

With MOFs

FIGURE 10 | Separation of solute by TFN membranes with and without MOFs (Liao et al., 2021).

TFC membranes modified with $\mathrm{Cu}-\mathrm{Al}$ layered double hydroxide nanofillers were found to be less negative than the usual TFC membranes and a substantial improvement in the anti-fouling properties was observed indicated by an improvement in water flux by $14 \%$ (Tajuddin et al., 2019).

Biopolymer based nanocomposite films, which consist of single dimensional palygorskite (PAL) nanorods and double dimensional montmorillonite (MMT) nanoplatelets in the sodium alginate (SA) film resulted in an enhancement in the tensile stress and the capacity of water resistance of the film (Huang et al., 2018).

All of these above examples showcase some of the numerous recently developed mechanisms to enhance the applicability of thin film nanocomposites in desalination applications by improving the various properties like water permeability and salt rejection of the membrane(Figure 9).However, TFNs continue to have some limitations, especially those concerning the adverse effects of desalination processes on the environment. Some of these concerns have been discussed in Section 7.4.

\subsection{Environmental Concerns}

Thermal emissions, brine discharge and chemicals used in the process all contribute towards environmental pollution (Van der Bruggen and Vandecasteele, 2002). Thermal emissions are directly related to the electric power consumption in the process. Therefore, RO membranes show the least amount of thermal emissions (Van der Bruggen and Vandecasteele, 2002). The impact of brine discharge on the environment can be determined by the temperature and salinity of the waste stream (Van der Bruggen and Vandecasteele, 2002). Brine released at high temperatures in fresh water bodies can decrease the oxygen content of the water hence harming the 
microorganisms present in the water. Since RO process does not involve heating up the water like in MED or MSF, it causes less harm to the environment in this aspect. When evaluating the environmental impact, all chemical additives that have been added to the water have to be considered (Van der Bruggen and Vandecasteele, 2002). Chemicals that might be used to reduce fouling or scaling, enter fresh water bodies, causing water pollution (Van der Bruggen and Vandecasteele, 2002). Taking all factors into account, it can be seen that RO is the least destructive to surroundings (Sagle and Freeman, 2004).

However, as seen in the previous section, RO involves water wastage. In addition, the demineralized water obtained is unhealthy and the process requires energy input. RO also tends to make the water acidic and is unable to remove chlorine, chloramines, volatile organic compounds (VOCs) and pharmaceuticals. In fact, all conventional methods of water treatment have drawbacks. Ultrafiltration is incapable of removing dissolved inorganic components and involves high energy costs. In microfiltration, fouling is a very serious issue and requires regular cleaning. Similarly, in nanofiltration, membrane fouling results in these membranes having a very limited lifetime. Pre-treatment is often a necessity in the case of nanofiltration (Das et al., 2014).

It has been suggested that CNT membranes possess various favorable properties like anti-fouling function, low energy consumption and self-cleaning functions (Das et al., 2014). This makes them a good alternative to conventional water treatment technologies and they might help in eradicating the fresh water crisis very soon (Das et al., 2014).In the following Section 7.5, the future scope of thin film nanocomposite membrane and their requisite for design and development towards commercialization for various applications is elucidated.

\subsection{Future Perspective}

Hoek introduced thin film nanocomposite (TFN) RO membranes by incorporating nanoparticles in polyamide layer in 2007 (Jeong et al., 2007). Since then, the new nanoparticles and nanocomposites were researched. The TFN membranes exhibited greater potential in overcoming trade-off between permeability and selectivity. The TFN membranes provided improvement in chlorine resistance and antifouling properties (wang et al., 2011).Despite such unique properties, dispersion of hydrophilic nanoparticles and leaching of nanoparticles into retentate and permeate has raised the environmental concerns and need further research. As the world is facing shortage of freshwater, thin film nanocomposite (TFN) membranes are anticipated to accelerate desalination industry and it can be extended as selective membranes for $\mathrm{CO}_{2}$ separation (Wong et al., 2016).The incorporation of functionalized fillers such as $\mathrm{GO}, \mathrm{CNT}, \mathrm{TiO}_{2}, \mathrm{Ag}-\mathrm{TiO}_{2}, \mathrm{MOF}$ (Figure 10) or organic fillers for specific applications has the potential to enhance membrane performance (Kumar et al., 2020).Recently, an interlayer of nanomaterials (TFNi) membranes showed extraordinary improvement in water flux and selectivity that can be used for the removal of heavy metals and micropollutants at a large scale
(Yang et al., 2020).In the near future, high impact TFN membranes with antifouling and biofouling properties, chemical resistance, improved mechanical strength and thermal stability need to be produced by either predisposition of new types of functionalized nanofillers or organic fillers compatible with selective layers of respective membranes. Such design and development of TFN membranes may pave way for more robust membrane systems with increased performance and long term durability providing precise solutions for various commercial water treatment challenges.

\section{CONCLUSION}

The utilization of nanotechnology in different environments has upgraded the present day environmental engineering and science together with a fresh set of technology that emerged from nanotechnology. The emerged technology at nanoscale has stimulated the advanced utilization of innovative and low-cost techniques that are effective for separation techniques. TFNs are obtained as modifications of TFCs. This modification is in the form of nanoparticles being incorporated into a thin polyamide (PA) dense layer at the top of the TFC membrane, aimed at improving its performance. In particular for desalination, specific modifications are generally made such that the permeate flux increases with negligible changes in the salt rejection upon nanomaterials incorporation. The full potential of a material development is on its performance and feasibility. Both these parameters are being answered in the PA nanocomposites development. The TFNs are used diversely in all membrane based desalination techniques. The transport properties of the penetrants are highly modified with addition of nanoparticles. The functionality of the membrane surface is targeted on specific membrane foulants. A specific kind of requirement is always being supported with a nanocomposites preparation. One of the main limitations of the TFNs is the amount of loading of nanomaterials and effective means for its distribution and dispersion on the whole polymer matrix. The liberty to functionalize the nanomaterials using several chemical groups could also improve their homogenization inside the polymer matrix. It appears that the choice of membrane materials for future RO processes would depend largely on the desired permselectivity and the targeted foulants. This review has focused on a variety TFNs preparedand their enhanced properties for addressing specified desalination requirements. The feasibility of such robust technology specifically meeting environmental impact and energy demands is widely discussed in this review paving way for the progress in research towards the development of new thin film nanocomposite membrane synthesis and manufacturing methods for desalination applications.

\section{AUTHOR CONTRIBUTIONS}

JK contributed conception and design of research, manuscript editing and final submission. KRV contributed analysis, research 
and collection of references. OG wrote sections of the manuscript and developed database. KJ and AP contributed early research and analysis. KJ performed statistical analysis. AP organized database. NN wrote sections of manuscript and performed comparative analysis of Data.

\section{REFERENCES}

Al-Hobaib, A. S., Al-Sheetan, K. M., Shaik, M. R., Al-Andis, N. M., and AlSuhybani, M. S. (2015). Characterization and Evaluation of Reverse Osmosis Membranes Modified with Ag2O Nanoparticles to Improve Performance. Nanoscale Res. Lett. 10, 1-13. doi:10.1186/s11671-015-1080-3

Alam, J., Dass, L. A., Ghasemi, M., and Alhoshan, M. (2013). Synthesis and Optimization of PES-Fe3 O4 Mixed Matrix Nanocomposite Membrane: Application Studies in Water Purification. Polym. Compos. 34, 1870-1877. doi:10.1002/pc.22593

Amini, M., Jahanshahi, M., and Rahimpour, A. (2013). Synthesis of Novel Thin Film Nanocomposite (TFN) Forward Osmosis Membranes Using Functionalized Multi-Walled Carbon Nanotubes. J. Membr. Sci. 435, 233-241. doi:10.1016/j.memsci.2013.01.041

Bao, M., Zhu, G., Wang, L., Wang, M., and Gao, C. (2013). Preparation of Monodispersed Spherical Mesoporous Nanosilica-Polyamide Thin Film Composite Reverse Osmosis Membranes via Interfacial Polymerization. Desalination 309, 261-266. doi:10.1016/j.desal.2012.10.028

Baroña, G. N. B., Choi, M., and Jung, B. (2012). High Permeate Flux of PVA/PSf Thin Film Composite Nanofiltration Membrane with Aluminosilicate SingleWalled Nanotubes. J. Colloid Interf. Sci. 386, 189-197. doi:10.1016/j.jcis.2012. 07.049

Baroña, G. N. B., Lim, J., Choi, M., and Jung, B. (2013). Interfacial Polymerization of Polyamide-Aluminosilicate SWNT Nanocomposite Membranes for Reverse Osmosis. Desalination 325, 138-147. doi:10.1016/j.desal.2013.06.026

Bates, W. T., and Cuozzo, R. (2000). Integrated Membrane Systems. Oceanside, CA: Hydranautics, Nitto Group Company. Available from: http://www.membranes. com/docs/papers/01_ims.pdf.

Bohdziewicz, J., Bodzek, M., and Wąsik, E. (1999). The Application of Reverse Osmosis and Nanofiltration to the Removal of Nitrates from Groundwater. Desalination 121, 139-147. doi:10.1016/s0011-9164(99)00015-6

Buonomenna, M. G. (2013). Nano-enhanced Reverse Osmosis Membranes. Desalination 314, 73-88. doi:10.1016/j.desal.2013.01.006

Chan, W.-F., Chen, H.-y., Surapathi, A., Taylor, M. G., Shao, X., Marand, E., et al. (2013). Zwitterion Functionalized Carbon Nanotube/Polyamide Nanocomposite Membranes for Water Desalination. ACS Nano 7, 5308-5319. doi:10.1021/nn4011494

Chou, W.-L., Yu, D.-G., and Yang, M.-C. (2005). The Preparation and Characterization of Silver-Loading Cellulose Acetate Hollow Fiber Membrane for Water Treatment. Polym. Adv. Technol. 16, 600-607. doi:10.1002/pat.630

Daraei, P., Madaeni, S. S., Ghaemi, N., Salehi, E., Khadivi, M. A., Moradian, R., et al. (2012). Novel Polyethersulfone Nanocomposite Membrane Prepared by PANI/ Fe3O4 Nanoparticles with Enhanced Performance for $\mathrm{Cu}(\mathrm{II})$ Removal from Water. J. Membr. Sci. 415-416, 250-259. doi:10.1016/j.memsci.2012.05.007

Daraei, P., Madaeni, S. S., Salehi, E., Ghaemi, N., Ghari, H. S., Khadivi, M. A., et al. (2013). Novel Thin Film Composite Membrane Fabricated by Mixed Matrix Nanoclay/chitosan on PVDF Microfiltration Support: Preparation, Characterization and Performance in Dye Removal. J. Membr. Sci. 436, 97-108. doi:10.1016/j.memsci.2013.02.031

Das, R., Ali, M. E., Hamid, S. B. A., Ramakrishna, S., and Chowdhury, Z. Z. (2014). Carbon Nanotube Membranes for Water Purification: A Bright Future in Water Desalination. Desalination 336, 97-109. doi:10.1016/j.desal.2013.12.026

de Lannoy, C.-F., Jassby, D., Gloe, K., Gordon, A. D., and Wiesner, M. R. (2013). Aquatic Biofouling Prevention by Electrically Charged Nanocomposite Polymer Thin Film Membranes. Environ. Sci. Technol. 47, 2760-2768. doi:10.1021/es3045168

Duan, J., Litwiller, E., and Pinnau, I. (2015a). Preparation and Water Desalination Properties of POSS-Polyamide Nanocomposite Reverse Osmosis Membranes. J. Membr. Sci. 473, 157-164. doi:10.1016/j.memsci.2014.09.022

\section{FUNDING}

This work was supported by the Early Career Research Award (DST-SERB), India ECR/2015/000014 and the Grant of OPERA Award from BITS Pilani FR/SCM/290513/CHEG.

Duan, J., Pan, Y., Pacheco, F., Litwiller, E., Lai, Z., and Pinnau, I. (2015b). Highperformance Polyamide Thin-Film-Nanocomposite Reverse Osmosis Membranes Containing Hydrophobic Zeolitic Imidazolate Framework-8. J. Membr. Sci. 476, 303-310. doi:10.1016/j.memsci.2014.11.038

Ettouney, H. M., El-Sessouky, H. T., Faibish, R. S., and Gowin, P. J. (2002). Evaluating the Economics of Desalination. Chem. Eng. Prog. 98 (46), 32-39.

Fathizadeh, M., Aroujalian, A., and Raisi, A. (2011). Effect of Added NaX NanoZeolite into Polyamide as a Top Thin Layer of Membrane on Water Flux and Salt Rejection in a Reverse Osmosis Process. J. Membr. Sci. 375, 88-95. doi:10. 1016/j.memsci.2011.03.017

Gai, W., Zhao, D. L., and Chung, T.-S. (2019). Thin Film Nanocomposite Hollow Fiber Membranes Comprising Na+-Functionalized Carbon Quantum Dots for Brackish Water Desalination. Water Res. 154, 54-61. doi:10.1016/j.watres.2019. 01.043

Ghanbari, M., Emadzadeh, D., Lau, W. J., Matsuura, T., and Ismail, A. F. (2015). Synthesis and Characterization of Novel Thin Film Nanocomposite Reverse Osmosis Membranes with Improved Organic Fouling Properties for Water Desalination. RSC Adv. 5, 21268-21276. doi:10.1039/c4ra16177g

Ghosh, A. K., and Hoek, E. M. V. (2009). Impacts of Support Membrane Structure and Chemistry on Polyamide-Polysulfone Interfacial Composite Membranes. J. Membr. Sci. 336, 140-148. doi:10.1016/j.memsci.2009.03.024

Ghosh, A. K., Jeong, B.-H., Huang, X., and Hoek, E. M. V. (2008). Impacts of Reaction and Curing Conditions on Polyamide Composite Reverse Osmosis Membrane Properties. J. Membr. Sci. 311, 34-45. doi:10.1016/j.memsci.2007. 11.038

Greenlee, L. F., Lawler, D. F., Freeman, B. D., Marrot, B., and Moulin, P. (2009) Reverse Osmosis Desalination: Water Sources, Technology, and Today's Challenges. Water Res. 43, 2317-2348. doi:10.1016/j.watres.2009.03.010

Hermans, S., Bernstein, R., Volodin, A., and Vankelecom, I. F. J. (2015). Study of Synthesis Parameters and Active Layer Morphology of Interfacially Polymerized Polyamide-Polysulfone Membranes. Reactive Funct. Polym. 86, 199-208. doi:10.1016/j.reactfunctpolym.2014.09.013

Hermans, S., Mariën, H., Dom, E., Bernstein, R., and Vankelecom, I. F. J. (2014). Simplified Synthesis Route for Interfacially Polymerized Polyamide Membranes. J. Membr. Sci. 451, 148-156. doi:10.1016/j.memsci.2013.10.005

Hu, D., Xu, Z.-L., and Wei, Y.-M. (2013). A High Performance Silica-Fluoropolyamide Nanofiltration Membrane Prepared by Interfacial Polymerization. Separat. Purif. Techn. 110, 31-38. doi:10.1016/j.seppur.2013.03.001

Huang, D., Zhang, Z., Ma, Z., and Quan, Q. (2018). Effect of Natural Nanostructured Rods and Platelets on Mechanical and Water Resistance Properties of Alginate-Based Nanocomposites. Front. Chem. 6. doi:10.3389/ fchem.2018.00635

Huang, H., Qu, X., Ji, X., Gao, X., Zhang, L., Chen, H., et al. (2013a). Acid and Multivalent Ion Resistance of Thin Film Nanocomposite RO Membranes Loaded with Silicalite-1 Nanozeolites. J. Mater. Chem. A. 1, 11343. doi:10. $1039 / \mathrm{c} 3 \operatorname{ta} 12199 \mathrm{~b}$

Huang, H., Qu, X., Dong, H., Zhang, L., and Chen, H. (2013b). Role of NaA Zeolites in the Interfacial Polymerization Process towards a Polyamide Nanocomposite Reverse Osmosis Membrane. RSC Adv. 3, 8203. doi:10.1039/c3ra40960k

Jadav, G. L., Aswal, V. K., and Singh, P. S. (2010). SANS Study to Probe Nanoparticle Dispersion in Nanocomposite Membranes of Aromatic Polyamide and Functionalized Silica Nanoparticles. J. Colloid Interf. Sci. 351, 304-314. doi:10.1016/j.jcis.2010.07.028

Jadav, G. L., and Singh, P. S. (2009). Synthesis of Novel Silica-Polyamide Nanocomposite Membrane with Enhanced Properties. J. Membr. Sci. 328, 257-267. doi:10.1016/j.memsci.2008.12.014

Jamshidi Gohari, R., Lau, W. J., Matsuura, T., and Ismail, A. F. (2013). Fabrication and Characterization of Novel PES/Fe-Mn Binary Oxide UF Mixed Matrix Membrane for Adsorptive Removal of As(III) from Contaminated Water Solution. Separat. Purif. Techn. 118, 64-72. doi:10.1016/j.seppur.2013.06.043 
Jeon, S., and Lee, J. (2020). Rationally Designed In-Situ Fabrication of Thin Film Nanocomposite Membranes with Enhanced Desalination and Anti-biofouling Performance. J. Membr. Sci. 615, 118542. doi:10.1016/j.memsci.2020.118542

Jeong, B.-H., Hoek, E. M. V., Yan, Y., Subramani, A., Huang, X., Hurwitz, G., et al. (2007). Interfacial Polymerization of Thin Film Nanocomposites: A New Concept for Reverse Osmosis Membranes. J. Membr. Sci. 294, 1-7. doi:10. 1016/j.memsci.2007.02.025

Kesieme, U. K., Milne, N., Aral, H., Cheng, C. Y., and Duke, M. (2013). Economic Analysis of Desalination Technologies in the Context of Carbon Pricing, and Opportunities for Membrane Distillation. Desalination 323, 66-74. doi:10. 1016/j.desal.2013.03.033

Kim, C. K., Kim, J. H., Roh, I. J., and Kim, J. J. (2000). The Changes of Membrane Performance with Polyamide Molecular Structure in the Reverse Osmosis Process. J. Membr. Sci. 165, 189-199. doi:10.1016/s0376-7388(99)00232-x

Kim, E.-S., and Deng, B. (2011). Fabrication of Polyamide Thin-Film NanoComposite (PA-TFN) Membrane with Hydrophilized Ordered Mesoporous Carbon (H-OMC) for Water Purifications. J. Membr. Sci. 375, 46-54. doi:10. 1016/j.memsci.2011.01.041

Kim, E.-S., Hwang, G., Gamal El-Din, M., and Liu, Y. (2012). Development of Nanosilver and Multi-Walled Carbon Nanotubes Thin-Film Nanocomposite Membrane for Enhanced Water Treatment. J. Membr. Sci. 394-395, 37-48. doi:10.1016/j.memsci.2011.11.041

Kim, I. C., Ka, Y. H., Park, J. Y., and Lee, K. H. (2004). Preparation of Fouling Resistant Nanofiltration and Reverse Osmosis Membranes and Their Use for Dyeing Wastewater Effluent. J. Ind. Eng. Chem. 10, 115-121.

Kim, S. G., Chun, J. H., Chun, B.-H., and Kim, S. H. (2013). Preparation, Characterization and Performance of Poly(aylene Ether Sulfone)/modified Silica Nanocomposite Reverse Osmosis Membrane for Seawater Desalination. Desalination 325, 76-83. doi:10.1016/j.desal.2013.06.017

Kim, E.-S., Liu, Y., and Gamal El-Din, M. (2013). An In-Situ Integrated System of Carbon Nanotubes Nanocomposite Membrane for Oil Sands Process-Affected Water Treatment. J. Membr. Sci. 429, 418-427. doi:10.1016/j.memsci.2012.11.077

Kim, S. G., Hyeon, D. H., Chun, J. H., Chun, B.-H., and Kim, S. H. (2013). Nanocomposite Poly(arylene Ether Sulfone) Reverse Osmosis Membrane Containing Functional Zeolite Nanoparticles for Seawater Desalination. J. Membr. Sci. 443, 10-18. doi:10.1016/j.memsci.2013.03.065

Kong, C., koushima, A., Kamada, T., Shintani, T., Kanezashi, M., Yoshioka, T., et al. (2011). Enhanced Performance of Inorganic-Polyamide Nanocomposite Membranes Prepared by Metal-Alkoxide-Assisted Interfacial Polymerization. J. Membr. Sci. 366, 382-388. doi:10.1016/j.memsci.2010.10.026

Kumar, M., Khan, M. A., and Arafat, H. A. (2020). Recent Developments in the Rational Fabrication of Thin Film Nanocomposite Membranes for Water Purification and Desalination. ACS Omega 5, 3792-3800. doi:10.1021/ acsomega.9b03975

Lau, W. J., Gray, S., Matsuura, T., Emadzadeh, D., Paul Chen, J., and Ismail, A. F. (2015). A Review on Polyamide Thin Film Nanocomposite (TFN) Membranes: History, Applications, Challenges and Approaches. Water Res. 80, 306-324. doi:10.1016/j.watres.2015.04.037

Lau, W. J., Ismail, A. F., Misdan, N., and Kassim, M. A. (2012). A Recent Progress in Thin Film Composite Membrane: A Review. Desalination 287, 190-199. doi:10. 1016/j.desal.2011.04.004

Lee, H. S., Im, S. J., Kim, J. H., Kim, H. J., Kim, J. P., and Min, B. R. (2008). Polyamide Thin-Film Nanofiltration Membranes Containing $\mathrm{TiO} 2$ Nanoparticles. Desalination 219, 48-56. doi:10.1016/j.desal.2007.06.003

Lee, S. Y., Kim, H. J., Patel, R., Im, S. J., Kim, J. H., and Min, B. R. (2007). Silver Nanoparticles Immobilized on Thin Film Composite Polyamide Membrane: Characterization, Nanofiltration, Antifouling Properties. Polym. Adv. Technol. 18, 562-568. doi:10.1002/pat.918

Li, D., and Wang, H. (2010). Recent Developments in Reverse Osmosis Desalination Membranes. J. Mater. Chem. 20, 4551. doi:10.1039/b924553g

Li, D., and Wang, H. (2013). "Thin Film Nanocomposite Membranes for Water Desalination," in Functional Nanostructured Materials and Membranes for Water Treatment. Editors M. Duke, D. Zhao, and R. Semiat (Weinheim, Germany: Wiley-VCH Verlag GmbH \& Co. KGaA). doi:10.1002/ 9783527668502.ch7

Li, D., and Wang, H. (2013). "Thin Film Nanocomposite Membranes for Water Desalination," in Functional Nanostructured Materials and Membranes for Water Treatment, 163-194. doi:10.1002/9783527668502.ch7
Li, X., Wang, R., Wicaksana, F., Tang, C., Torres, J., and Fane, A. G. (2014). Preparation of High Performance Nanofiltration (NF) Membranes Incorporated with Aquaporin Z. J. Membr. Sci. 450, 181-188. doi:10.1016/j. memsci.2013.09.007

Liao, Z., Zhu, J., Li, X., and Van Der Bruggen, B. (2021). Regulating Composition and Structure of Nanofillers in Thin Film Nanocomposite (TFN) Membranes for Enhanced Separation Performance: A Critical Review. Separat. Purif. Techn. 266, 118567. doi:10.1016/j.seppur.2021.118567

Lind, M. L., Eumine Suk, D., Nguyen, T.-V., and Hoek, E. M. V. (2010). Tailoring the Structure of Thin Film Nanocomposite Membranes to Achieve Seawater RO Membrane Performance. Environ. Sci. Technol. 44, 8230-8235. doi:10.1021/ es101569p

Lind, M. L., Ghosh, A. K., Jawor, A., Huang, X., Hou, W., Yang, Y., et al. (2009a). Influence of Zeolite Crystal Size on Zeolite-Polyamide Thin Film Nanocomposite Membranes. Langmuir 25, 10139-10145. doi:10.1021/ la900938x

Lind, M. L., Jeong, B.-H., Subramani, A., Huang, X., and Hoek, E. M. V. (2009b). Effect of mobile Cation on Zeolite-Polyamide Thin Film Nanocomposite Membranes. J. Mater. Res. 24, 1624-1631. doi:10.1557/jmr.2009.0189

Liu, Y., Wang, X., Yang, F., and Yang, X. (2008). Excellent Antimicrobial Properties of Mesoporous Anatase $\mathrm{TiO} 2$ and $\mathrm{Ag} / \mathrm{TiO} 2$ Composite Films. Microporous Mesoporous Mater. 114, 431-439. doi:10.1016/j.micromeso.2008.01.032

Louie, J. S., Pinnau, I., Ciobanu, I., Ishida, K. P., Ng, A., and Reinhard, M. (2006). Effects of Polyether-Polyamide Block Copolymer Coating on Performance and Fouling of Reverse Osmosis Membranes. J. Membr. Sci. 280, 762-770. doi:10. 1016/j.memsci.2006.02.041

Lu, M. (2013). in Functional Nanostructured Materials and Membranes for Water Treatment. Editors M. Duke, D. Zhao, and R. Semiat (Weinheim, Germany: Wiley-VCH Verlag GmbH \& Co. KGaA).

Ma, H., Yoon, K., Rong, L., Shokralla, M., Kopot, A., Wang, X., et al. (2010). ThinFilm Nanofibrous Composite Ultrafiltration Membranes Based on Polyvinyl Alcohol Barrier Layer Containing Directional Water Channels. Ind. Eng. Chem. Res. 49, 11978-11984. doi:10.1021/ie100545k

Ma, N., Wei, J., Liao, R., and Tang, C. Y. (2012). Zeolite-polyamide Thin Film Nanocomposite Membranes: Towards Enhanced Performance for Forward Osmosis. J. Membr. Sci. 405-406, 149-157. doi:10.1016/j.memsci.2012.03.002

Mickley, M. C. (2001). Membrane Concentrate Disposal: Practices and Regulation. Denver, ColoradoUS Department of the Interior, Bureau of Reclamation, Technical Service Center, Water Treatment Engineering and Research Group. Final Report.

Mills, A., and Le Hunte, S. (1997). An Overview of Semiconductor Photocatalysis. J. Photochem. Photobiol. A: Chem. 108, 1-35. doi:10.1016/s1010-6030(97) 00118-4

NanoH2O, Inc. InterNano (2021). Internano.org. Available at: https://www. internano.org/node/1516 (Accessed May 22, 2021).

Park, H. B., Freeman, B. D., Zhang, Z.-B., Sankir, M., and McGrath, J. E. (2008) Highly Chlorine-Tolerant Polymers for Desalination. Angew. Chem. Int. Edition 47, 6019-6024. doi:10.1002/anie.200800454

Park, K. T., Kim, S. G., Chun, B.-H., Bang, J., and Kim, S. H. (2010). Sulfonated Poly(arylene Ether Sulfone) Thin-Film Composite Reverse Osmosis Membrane Containing SiO2 Nano-Particles. $d w t$ 15, 69-75. doi:10.5004/dwt.2010.1669

Park, J., Choi, W., Kim, S. H., Chun, B. H., Bang, J., and Lee, K. B. (2010). Enhancement of Chlorine Resistance in Carbon Nanotube Based Nanocomposite Reverse Osmosis Membranes. Desalination Water Treat. 15, 198-204. doi:10.5004/dwt.2010.1686

Paz, Y. (2010). Application of TiO2 Photocatalysis for Air Treatment: Patents' Overview. Appl. Catal. B: Environ. 99, 448-460. doi:10.1016/j.apcatb.2010. 05.011

Pendergast, M. M., Ghosh, A. K., and Hoek, E. M. V. (2013). Separation Performance and Interfacial Properties of Nanocomposite Reverse Osmosis Membranes. Desalination 308, 180-185. doi:10.1016/j.desal.2011.05.005

Pendergast, M. M., and Hoek, E. M. V. (2011). A Review of Water Treatment Membrane Nanotechnologies. Energy Environ. Sci. 4, 1946. doi:10.1039/ c0ee00541j

Petersen, R. J. (1993). Composite Reverse Osmosis and Nanofiltration Membranes. J. Membr. Sci. 83, 81-150. doi:10.1016/0376-7388(93)80014-o

Rahimpour, A., Madaeni, S. S., Taheri, A. H., and Mansourpanah, Y. (2008). Coupling $\mathrm{TiO} 2$ Nanoparticles with UV Irradiation for Modification of 
Polyethersulfone Ultrafiltration Membranes. J. Membr. Sci. 313, 158-169. doi:10.1016/j.memsci.2007.12.075

Rajaeian, B., Rahimpour, A., Tade, M. O., and Liu, S. (2013). Fabrication and Characterization of Polyamide Thin Film Nanocomposite (TFN) Nanofiltration Membrane Impregnated with $\mathrm{TiO} 2$ Nanoparticles. Desalination 313, 176-188. doi:10.1016/j.desal.2012.12.012

Rajakumaran, R., Kumar, M., and Chetty, R. (2020). Morphological Effect of ZnO Nanostructures on Desalination Performance and Antibacterial Activity of Thin-Film Nanocomposite (TFN) Membrane. Desalination 495, 114673. doi:10.1016/j.desal.2020.114673

Rana, D., Kim, Y., Matsuura, T., and Arafat, H. A. (2011). Development of Antifouling Thin-Film-Composite Membranes for Seawater Desalination. J. Membr. Sci. 367, 110-118. doi:10.1016/j.memsci.2010.10.050

Rana, T. M. D., Qtaishat, M. R., and Singh, G. (2011). "Recent Advances in Membrane Science and Technology in Seawater Desalination-With Technology Development in the Middle East and Singapore," in Water and Water Treatment Technologies, Encyclopedia of Life Support Systems (EOLSS), Developed under the Auspices of the UNESCO (Oxford, UK: Eolss Publishers).

Reahl, E. R. (2004). Half a Century of Desalination with Electrodialysis. New York, NY: General Electric Company.

Roy, S., Ntim, S. A., Mitra, S., and Sirkar, K. K. (2011). Facile Fabrication of superior Nanofiltration Membranes from Interfacially Polymerized CNTPolymer Composites. J. Membr. Sci. 375, 81-87. doi:10.1016/j.memsci.2011. 03.012

Safarpour, M., Khataee, A., and Vatanpour, V. (2015). Thin Film Nanocomposite Reverse Osmosis Membrane Modified by Reduced Graphene oxide/TiO 2 with Improved Desalination Performance. J. Membr. Sci. 489, 43-54. doi:10.1016/j. memsci.2015.04.010

Sagle, A., and Freeman, B. (2004). Fundamentals of Membranes for Water Treatment. Future desalination Tex. 2, 137-154.

Saleem, H., and Zaidi, S. J. (2020). Nanoparticles in Reverse Osmosis Membranes for Desalination: A State of the Art Review. Desalination 475, 114171. doi:10. 1016/j.desal.2019.114171

Saleh, T. A., and Gupta, V. K. (2012). Synthesis and Characterization of Alumina NanoParticles Polyamide Membrane with Enhanced Flux Rejection Performance. Separat. Purif. Techn. 89, 245-251. doi:10.1016/j.seppur.2012.01.039

Shahzad, M. W., Burhan, M., and Ng, K. C. (2019). A Standard Primary Energy Approach for Comparing Desalination Processes. Npj Clean. Water 2, 1. doi:10. 1038/s41545-018-0028-4

Shen, J. n., Yu, C. c., Ruan, H. m., Gao, C. j., and Van der Bruggen, B. (2013). Preparation and Characterization of Thin-Film Nanocomposite Membranes Embedded with Poly(methyl Methacrylate) Hydrophobic Modified Multiwalled Carbon Nanotubes by Interfacial Polymerization. J. Membr. Sci. 442, 18-26. doi:10.1016/j.memsci.2013.04.018

Shenvi, S. S., Isloor, A. M., and Ismail, A. F. (2015). A Review on RO Membrane Technology: Developments and Challenges. Desalination 368, 10-26. doi:10. 1016/j.desal.2014.12.042

Siew Khoo, Y., Jye Lau, W., Yeow Liang, Y., Karaman, M., Gürsoy, M., and Fauzi Ismail, A. (2021). Eco-friendly Surface Modification Approach to Develop Thin Film Nanocomposite Membrane with Improved Desalination and Antifouling Properties. J. Adv. Res., 1-27. doi:10.1016/j.jare.2021.06.011

Singh, P. S., and Aswal, V. K. (2008). Characterization of Physical Structure of Silica Nanoparticles Encapsulated in Polymeric Structure of Polyamide Films. J. Colloid Interf. Sci. 326, 176-185. doi:10.1016/j.jcis.2008.07.025

Subramani, A., Voutchkov, N., and Jacangelo, J. G. (2014). Desalination Energy Minimization Using Thin Film Nanocomposite Membranes. Desalination 350, 35-43. doi:10.1016/j.desal.2014.07.011

Tajuddin, M. H., Yusof, N., Wan Azelee, I., Wan Salleh, W. N., Ismail, A. F., Jaafar, J., et al. (2019). Development of Copper-Aluminum Layered Double Hydroxide in Thin Film Nanocomposite Nanofiltration Membrane for Water Purification Process. Front. Chem. 7. doi:10.3389/fchem.2019.00003

The World Bank (2007). IDA at Work: Water Resources - Improving Services for the Poor. Washington DC.

UNESCO (2020). The United Nations World Water Development Report 2020: Water and Climate Change. Paris.

Van der Bruggen, B., and Vandecasteele, C. (2002). Distillation vs. Membrane Filtration: Overview of Process Evolutions in Seawater Desalination. Desalination 143, 207-218. doi:10.1016/s0011-9164(02)00259-x
Wade, N. M. (2001). Distillation Plant Development and Cost Update. Desalination 136, 3-12. doi:10.1016/s0011-9164(01)00159-x

Wade, N. M. (1993). Technical and Economic Evaluation of Distillation and Reverse Osmosis Desalination Processes. Desalination 93, 343-363. doi:10. 1016/0011-9164(93)80113-2

Wan Azelee, I., Goh, P. S., Lau, W. J., Ismail, A. F., Rezaei-DashtArzhandi, M., Wong, K. C., et al. (2017). Enhanced Desalination of Polyamide Thin Film Nanocomposite Incorporated with Acid Treated Multiwalled Carbon Nanotube-Titania Nanotube Hybrid. Desalination 409, 163-170. doi:10. 1016/j.desal.2017.01.029

Wang, J., Wang, Q., Gao, X., Tian, X., Wei, Y., Cao, Z., et al. (2019). Surface Modification of Mesoporous Silica Nanoparticle with 4-triethoxysilylaniline to Enhance Seawater Desalination Properties of Thin-Film Nanocomposite Reverse Osmosis Membranes. Front. Environ. Sci. Eng. 14. doi:10.1007/ s11783-019-1185-5

wang, L. K., Chen, J. P., Hung, Y. - T., and Shammas, N. K. (2011). Handbook of Environmental Engineering: Membrane and Desalination Technologies. New York, NY: Springer Science+ Business Media, LLC, 13, 1-699. doi:10.1007/9781-59745-278-6_1

Wang, X., Chen, X., Yoon, K., Fang, D., Hsiao, B. S., and Chu, B. (2005). High Flux Filtration Medium Based on Nanofibrous Substrate with Hydrophilic Nanocomposite Coating. Environ. Sci. Technol. 39, 7684-7691. doi:10.1021/ es $050512 \mathrm{j}$

Williams, M. E. (2003). A Brief Review of Reverse Osmosis Membrane Technology. EET Corporation and Williams Engineering Services Company Inc.

Wong, K. C., Goh, P. S., and Ismail, A. F. (2016). Thin Film Nanocomposite: the Next Generation Selective Membrane for CO2 Removal. J. Mater. Chem. A. 4, 15726-15748. doi:10.1039/c6ta05145f

$\mathrm{Wu}, \mathrm{H}$. , Tang, B., and $\mathrm{Wu}, \mathrm{P}$. (2010). MWNTs/Polyester Thin Film Nanocomposite Membrane: An Approach to Overcome the Trade-Off Effect between Permeability and Selectivity. J. Phys. Chem. C 114, 16395-16400. doi:10.1021/jp107280m

$\mathrm{Wu}, \mathrm{H}$., Tang, B., and Wu, P. (2013a). Optimization, Characterization and Nanofiltration Properties Test of MWNTs/polyester Thin Film Nanocomposite Membrane. J. Membr. Sci. 428, 425-433. doi:10.1016/j. memsci.2012.10.042

Wu, H., Tang, B., and Wu, P. (2013b). Optimizing Polyamide Thin Film Composite Membrane Covalently Bonded with Modified Mesoporous Silica Nanoparticles. J. Membr. Sci. 428, 341-348. doi:10.1016/j.memsci. 2012.10.053

Yang, Z., Sun, P.-F., Li, X., Gan, B., Wang, L., Song, X., et al. (2020). A Critical Review on Thin-Film Nanocomposite Membranes with Interlayered Structure: Mechanisms, Recent Developments, and Environmental Applications. Environ. Sci. Technol. 54, 15563-15583. doi:10.1021/acs.est.0c05377

Yin, J., Kim, E.-S., Yang, J., and Deng, B. (2012). Fabrication of a Novel Thin-Film Nanocomposite (TFN) Membrane Containing MCM-41 Silica Nanoparticles (NPs) for Water Purification. J. Membr. Sci. 423-424, 238-246. doi:10.1016/j. memsci.2012.08.020

You, H., Li, X., Yang, Y., Wang, B., Li, Z., Wang, X., et al. (2013). High Flux Low Pressure Thin Film Nanocomposite Ultrafiltration Membranes Based on Nanofibrous Substrates. Separat. Purif. Techn. 108, 143-151. doi:10.1016/j. seppur.2013.02.014

You, H., Zhang, X., Zhu, D., Yang, C., Chammingkwan, P., and Taniike, T. (2021) Advantages of Polydopamine Coating in the Design of ZIF-8-Filled Thin-Film Nanocomposite (TFN) Membranes for Desalination. Colloids Surf. A: Physicochemical Eng. Aspects 629, 127492. doi:10.1016/j.colsurfa.2021.127492

Yu, C. C., Yu, H. W., Chu, Y. X., Ruan, H. M., and Shen, J. N. (2013). Preparation Thin Film Nanocomposite Membrane Incorporating PMMA Modified MWNT for Nanofiltration. Kem 562-565, 882-886. doi:10.4028/www.scientific.net/ kem.562-565.882

Zargar, M., Hartanto, Y., Jin, B., and Dai, S. (2017). Understanding Functionalized Silica Nanoparticles Incorporation in Thin Film Composite Membranes: Interactions and Desalination Performance. J. Membr. Sci. 521, 53-64. doi:10.1016/j.memsci.2016.08.069

Zhang, L., Shi, G.-Z., Qiu, S., Cheng, L.-H., and Chen, H.-L. (2011). Preparation of High-Flux Thin Film Nanocomposite Reverse Osmosis Membranes by Incorporating Functionalized Multi-Walled Carbon Nanotubes. Desalination Water Treat. 34, 19-24. doi:10.5004/dwt.2011.2801 
Zhao, D. L., Japip, S., Zhang, Y., Weber, M., Maletzko, C., and Chung, T.-S. (2020). Emerging Thin-Film Nanocomposite (TFN) Membranes for Reverse Osmosis: A Review. Water Res. 173, 115557. doi:10.1016/j.watres.2020. 115557

Zhao, H., Qiu, S., Wu, L., Zhang, L., Chen, H., and Gao, C. (2014). Improving the Performance of Polyamide Reverse Osmosis Membrane by Incorporation of Modified Multi-Walled Carbon Nanotubes. J. Membr. Sci. 450, 249-256. doi:10. 1016/j.memsci.2013.09.014

Zhao, R. (2013). Theory and Operation of Capacitive Deionization Systems. Weinheim: Wiley-VCH Verlag GmbH \& C. KGaA.

Zhao, Y., Qiu, C., Li, X., Vararattanavech, A., Shen, W., Torres, J., et al. (2012). Synthesis of Robust and High-Performance Aquaporin-Based Biomimetic Membranes by Interfacial Polymerization-Membrane Preparation and RO Performance Characterization. J. Membr. Sci. 423-424, 422-428. doi:10. 1016/j.memsci.2012.08.039

Zhou, Y., Yu, S., Gao, C., and Feng, X. (2009). Surface Modification of Thin Film Composite Polyamide Membranes by Electrostatic Self Deposition of Polycations for Improved Fouling Resistance. Separat. Purif. Techn. 66, 287-294. doi:10.1016/j.seppur.2008.12.021

Zhu, X., Bai, R., Wee, K.-H., Liu, C., and Tang, S.-L. (2010). Membrane Surfaces Immobilized with Ionic or Reduced Silver and Their Anti-biofouling Performances. J. Membr. Sci. 363, 278-286. doi:10.1016/j.memsci.2010.07.041
Zodrow, K., Brunet, L., Mahendra, S., Li, D., Zhang, A., Li, Q., et al. (2009). Polysulfone Ultrafiltration Membranes Impregnated with Silver Nanoparticles Show Improved Biofouling Resistance and Virus Removal. Water Res. 43, 715-723. doi:10.1016/j.watres.2008.11.014

Conflict of Interest: The authors declare that the research was conducted in the absence of any commercial or financial relationships that could be construed as a potential conflict of interest.

Publisher's Note: All claims expressed in this article are solely those of the authors and do not necessarily represent those of their affiliated organizations, or those of the publisher, the editors and the reviewers. Any product that may be evaluated in this article, or claim that may be made by its manufacturer, is not guaranteed or endorsed by the publisher.

Copyright (C) 2022 Nambi Krishnan, Venkatachalam, Ghosh, Jhaveri, Palakodeti and Nair. This is an open-access article distributed under the terms of the Creative Commons Attribution License (CC BY). The use, distribution or reproduction in other forums is permitted, provided the original author(s) and the copyright owner(s) are credited and that the original publication in this journal is cited, in accordance with accepted academic practice. No use, distribution or reproduction is permitted which does not comply with these terms. 